\title{
A DOLMÁNYOS VARJÚ (Corvus cornix) KEZELÉSI TERVE MAGYARORSZÁGON
}

\author{
Faragó Sándor, Kovács Gyula \& Hajas Péter Pál \\ Soproni Egyetem, Vadgazdálkodási és Gerinces Állattani Intézet \\ University of Sopron, Institute of Wildlife Management and Vertebrate Zoology \\ H-9400 Sopron, Bajcsy-Zs u. 4., Hungary \\ email: farago.sandor@uni-sopron.hu; gyuszkovar@yahoo.com; pphajas@gmail.com
}

FARAGÓ S., KovÁcs Gy. \& HAJAS P.P.: MANAGEMENT PLAN FOR HOODED CROW (Corvus cornix) IN HUNGARY. Hungarian Small Game Bulletin 13: 15-48. http://dx.doi.org/10.17243/mavk.2017.015

\section{A DOLMÁNYOS VARJÚ (Corvus cornix) BIOLÓGIÁJA ÉS ÖKOLÓGIÁJA, A KEZELÉSI GYAKORLAT ÉRTÉKELÉSE}

\subsection{BEVEZETÉS}

Európában stabil (S) állományú faj (TUCKER \& HEATH 1994). A Berni Egyezmény III. Mellékletében és az EU Madárvédelmi Irányelvek II/2 Mellékletében található. A dolmányos varjú korábban egész évben vadászható volt Magyarországon, amit az EU madárvédelmi irányelv - fészkelő populáció védelme - alapján július 1. - február 28(29). közti időszakra kellett módosítani. E változás következményei beláthatatlanok lennének mind a vadgazdálkodás, mind a természetvédelem számára - a faj madárfészekben okozott kártétele miatt -, de a vadászati rendelet, apróvadas vadászterületeken, az apróvad szaporodási időszakában, a vadászati hatóság külön engedélyéhez kötve lehetővé teszi gyérítését. Mivel fészke a később érkező kékvércse (Falco vespertinus) és a másodköltést folytató erdei fülesbagoly (Asio otus) számára igen fontos, célszerű a gyérítését a fészeképítés, vagy tatarozás után megkezdeni. Így a védett madarak is fészkelő helyhez jutnak és a vadászható fajok fészkeinek kifosztása is megelőzhető. Természetvédelmi szempontból is indokolt állományának alacsony sürüségen való tartása.

Egybehangzó vizsgálatok mutatják szerte Európában, hogy a földön fészkelő szárnyas apróvad állomány egyik legfontosabb predátora, fészkeinek pusztítója. A vadászható fajokon kívül a védett fajokra is kedvezötlen a hatásuk, ezért gyérítése minden a jog keretei között alkalmazható eszközzel szükséges, sőt kötelező.

$\mathrm{Az}$ ismertetésre kerülő táplálkozási vizsgálatok alapján a kedvezőtlen megítélése ugyan eltúlzott, viszont az is igaz, hogy a tojásfogyasztás nehezen mutatható ki a gyomortartalomból. A szárnyas apróvad, különösen a fogoly természetes populációinak fenntartása magas dolmányos varjú (és szarka) sürüség mellett nagy nehézségekbe ütközik (POTTS, 1986). Ez a szerepe nem tudatosult a vadgazdákban, amit igazol a folyamatosan csökkenő teríték. Mivel a korábban használt preparált tojások felvétele után az elpusztult dolmányos varjak tetemeinek egy része elveszett, bizonyos, hogy az eltávolított egyedek száma a statisztikákban a korábban közöltnél is jóval magasabb volt. 


\section{2. ÖKOLÓGIA}

\subsection{1. Élőhelyi feltételek}

A dolmányos varjú mindenütt előfordul hazánkban, de az összefüggő nagy erdőségeknek csak a peremén telepedhet meg. Kedveli a fasorokkal, erdősávokkal, erdőfoltokkal tarkított mezőgazdasági tájat, ártéri liget- és galériaerdőket. Európa más területein gyakori jelenség, de nálunk is megkezdődött települések belsejébe való költözése, amely föként Budapesten, de pl. a Balaton parton öltött jelentős méretet. A kormos varjú Magyarországon a mezőgazdasági területeket tagoló fasorokban, erdősávokban, ligeterdőkben, galériaerdőkben és erdőszegélyekben telepszik meg, táplálékát pedig a mezőgazdasági területeken gyüjti (FARAGÓ, 2015).

\subsubsection{Szaporodás}

A két faj (korábban alfaj) szaporodása igen hasonló, ami lehető is teszi hibridizációjukat.

Ivarérettség: Az egyedek biológiailag már első éves korukban érettek, de csak a 3-5. évben fognak hozzá a szaporodáshoz (GLUTZ VON BLOTZHEIM \& BAUER, 1993).

Ivari kapcsolata: A dolmányos varjú monogám, tartós párkapcsolattal. A még szaporodásra nem kész, fiatal madarak a szaporodási időszakban is többé-kevésbé zárt csapatokban maradnak. Párképzés már ekkor megfigyelhető, ami a közös repülésekkel is igazolható. Tavasszal egyes egyedek, vagy párok csapataik fö táplálkozó területeit rövid időre elhagyják és felderítik a környéket. Olykor ezek a madarak végül territóriumot foglalnak, de továbbra is a csapat közös pihenőhelyén éjszakáznak. Mások csak a következő évben foglalnak territóriumot, vagy az előző évben felderített területen, vagy annak közelében. A szülők általában segítik a fiatalokat a szomszédokkal szemben a territórium megszerzésében. Az udvarlás viszonylag egyszerü mozdulatokkal és hangadással történik, minél régebbi a párkapcsolat, annál egyszerübb annak lefolyása. A párzás rendszerint a fészekben, vagy annak közvetlen közelében játszódik le, időtartama 10-15 másodperc. Territoriális, vagy territórium nélküli hímnek a szomszéd territóriumban kotló tojón elkövetett erőszakos párzását csakúgy megfigyelték, mint egy közelben kotló egerészölyv (!) tojón tett, eröszakos párzási kísérletét (GLUTZ VON BLOTZHEIM \& BAUER, 1993).

Költési idő: Március elején történik a fészkelő helyek elfoglalása, a fészektatarozás, vagy új fészek építése. Közép-Európában március közepén kezdődik és május elejéig tart a tojások lerakása.

A fészek helye: A fészkeket réteken és szántókon növő magányos fákon, fasorokban, erdősávokban, erdők szegélyében rakja. Magyarországon gyűjtött dolmányos varjú fészekaljak $(n=46)$ tartófa fajai az alábbiak voltak: füzek - 22 fészek $(47,8 \%)$, nyárak -8 fészek (17,3\%), akác - 4 fészek (8,7\%), éger és kőrisek - 3-3 fészek (6,5-6,5\%), erdei fenyő, vadkörte, mezei juhar, cser, gyertyán, eper (Morus alba) - 1-1 fészek (2,2-2,2\%). A fészekrakás átlagos magassága (n=45): 6,4 (3-13) m (FARAGÓ, 2001a).

Fészke: Fészkét, amely elég terjedelmes és stabil alkotmány, a két szülő fák lombkoronájának felső felében építi meg. A hím elsősorban a fészekanyagok hordását végzi. A fészek alapját (átmérője mintegy $40 \mathrm{~cm}$ ) száraz faágakból, gallyakból, gyökerekből készíti, majd nedves sárral belülröl kitapasztja és puha anyagokkal (toll, füszálak stb.) béleli. A fészekcsésze $16 \mathrm{~cm}$ széles és $12 \mathrm{~cm}$ mély (MAKATSCH, 1976). 
Tojásrakás, költésszám: Évente egy költése van, de fészekaljának pusztulása esetén sarjúfészket rak.

A fészekalj nagysága: (4-)5(-7) (HARRISON, 1975; MAKATSCH, 1976). Magyarországon gyüjtött 58 fészekaljak közül 4 tojás 15 esetben (25,9\%), 5 tojás 31 esetben $(53,4 \%), 6$ tojás pedig 12 esetben (20,7\%) fordult elő. Az átlagos fészekalj nagyság 4,9 tojás volt (FARAGÓ, 2001a).

A tojások mindhárom európai (al)fajnál azonosak, többnyire oválisak, de előfordulnak rövid ovális, hegyes ovális és nyújtott hegyes ovális formájúak is. Alapszínük zöldeskék - ritkán kékes árnyalattal - barna foltozással. A C. cornix tojások átlagmértei az alábbiak: KözépEurópa - $\mathrm{D}_{154}$ : 42,26 × 29,53 mm (MAKATsCH, 1976), Csehszlovákia - $\mathrm{D}_{334}: 41,49 \times 29,19$ mm (GLUTZ VON BLOTZHEIM \& BAUER, 1993). A C. cornix sardonius tojások átlagméretei: Görögország - $\mathrm{D}_{174}: 41,43 \times 29,19 \mathrm{~mm}$ (MAKATSCH, 1976). A C. corone tojások átlagméretei: Közép-Európa $-\mathrm{D}_{67}: 42,52 \times 29,63 \mathrm{~mm}$ (MAKATSCH, 1976). A tojás tömege 19,1 g (MAKATSCH, 1976). A Magyarországon mért $C$. cornix tojások $(n=287)$ jellemző értékei az alábbiak voltak (FARAGÓ, 2000d).

$\begin{array}{llll}\mathrm{D}_{287}: & 41,82 \times 29,26 \mathrm{~mm} & & \\ \mathrm{H}_{\text {min. }} & 36,85 \times 28,64 \mathrm{~mm} & \mathrm{H}_{\max .} & 48,19 \times 27,83 \mathrm{~mm} \\ \mathrm{Sz}_{\text {min. }} & 40,57 \times 25,83 \mathrm{~mm} & \mathrm{H}_{\max } & 44,60 \times 31,30 \mathrm{~mm} \\ \mathrm{I} & 1,431 & & \\ \mathrm{I}_{\min } & 1,27 & \mathrm{I}_{\max } & 1,73\end{array}$

Kotlás: Csak a tojó kotlik, a kotlás elkezdésében nagy egyedi változatosság tapasztalható. Megkezdhetik a kotlást az 1-3. tojások valamelyikének lerakása után, de az utolsó letojását követően is. Kotlása közben a hím eteti a tojót a fészken, vagy annak közelében. A fiókák 1820 nap után kelnek ki.

Fiókanevelés: A kelést követően is a hím szerzi a táplálékot, de kezdetben csak a tojó eteti a fiatalokat, később mindkét szülő kínálja nekik a táplálékot. A fiatalok 4-5 hetes korban hagyják el a fészket. Elöször a fészek környékén tartózkodnak, majd egy ideig még együtt jár a család. Augusztusban nagyobb csapatokba is verődnek.

Költési eredmény, halandóság, életkor: Egy dél-svédországi dolmányos varjú vizsgálat során a tojások $(\mathrm{n}=617)$ 8\%-a terméketlen volt, vagy korai stádiumban halt el az embrió, $\mathrm{s}$ fészekaljanként további 3 fióka pusztult el a kelés során. A 115 fészekaljból 93 kikelt, ez a fészkek $81 \%$-át, a tojások $\geq 75 \%$-át jelentette. A 20 napos kort közülük 60 fészekalj érte el. Az elpusztult fészekaljak 34\%-át a szülök sarjú-fészekaljakkal pótolták. A 4,3 tojás/fészekalj primer natalitáshoz 3,4 kikelt fióka/fészekalj szekunder natalitás és 2,8 fiatal/fészekalj felnevelt szaporulat, tercier natalitás volt rendelhető (LOMAN idézi GLUTZ VON BLOTZHEIM \& BAUER, 1993). Az első évben 73\%-os, később 27\%-os a halandóság. A legmagasabb ismert életkor dolmányos varjú esetében 19 év.

\subsubsection{Táplálkozás}

Magyarországon a dolmányos varjú $(\mathrm{n}=275)$ első táplálkozásvizsgálata (CSIKI, 1914) során 36 gyomor tisztán növényi, 86 egyednél tisztán állati, a fennmaradók vegyes táplálékmaradványokat tartalmaztak. A növényi komponens zömét termesztett növények (kukorica, búza, árpa, zab) magvai, a nyári időszakban gyümölcsök (cseresznye, eper Morus, szeder) képezték. A táplálékban - föleg a tavaszi időszakban - a bogaraké (Coleoptera) volt a domináns szerep, legalább 120 bogárfajt mutatott ki a szerző. Emellett az alábbi 
taxonok játszottak fontos szerepet: puhatestüek (Mollusca), százlábúak (Chilopoda), szitakötők (Odonata), egyenesszárnyúak (Orthoptera), poloskák (Heteroptera), lepkék (Lepidoptera), kétszárnyúak (Diptera), hártyásszárnyúak (Hymenoptera), pókalakúak (Araneidea), halak (Pisces), kétéltűek (Amphibia), hüllők (Reptilia), madarak (Aves), emlösök (Mammalia).

Több mint 50 évvel később STERBETz (1968) a dolmányos varjú (n=256) táplálékában - gyakoriságot tekintve - ugyancsak az állati eredetủ táplálékot találta meghatározónak (1. táblázat). A tavaszi időszakban 64\%-os, nyáron $87 \%$-os, ősszel pedig $58 \%$-os gyakorisággal vett fel rovarokat, emlősöket, madarakat, tojásokat, hüllöket. Az állati eredetü táplálék gyakorisága még télen is $42 \%$ volt, emlösök, madarak, hús (dög?) fogyasztásával. A haszonnövények magvai a téli időszakban a táplálék tömegének $32 \%$-át, tavasszal $22 \%$-át, nyáron $11 \%$-át, összel pedig 33\%-át tették ki.

Ha a tömegviszonyokat is figyelembe vesszük, mint ahogy azt KoSARAS (1986) is tette (2. táblázat), akkor kiderül, hogy az állati táplálék csak a tavaszi aspektusban meghatározó (43,5 tömeg \%), nyáron és ősszel viszonylag még magas (19.3 és 17,7\%), télen viszont elenyésző mértékü (6,8 tömeg \%). A táplálékban - a tavaszt leszámítva - mindig a haszonnövények magvai domináltak, nyáron $43,0 \%$, összel $52,0 \%$, télen pedig $73,6 \%$ értékkel. Tavasszal mindössze 0,3 tömeg \%-ban fogyasztotta haszonnövények magvait. Gyomnövény csak nyáron volt értékelhető mennyiségben $(2,2$ tömeg \%) a gyomrokban. Az egész év során magas $(19,6-56,2 \%)$ volt az egyéb növényi részek részesedése táplálékában, különösen kitünt ez a tavasz folyamán.

1. táblázat: A dolmányos varjú táplálékának összetétele STERBETZ (1968) alapján Table 1: Composition of Hooded Crow's diet in Hungary (STERBETZ, 1968)

\begin{tabular}{lcccc}
\hline Táplálék (\%) - Diet & Dec. - Márc. & Ápr. - Máj. & Jún. -Aug. & Szept. - Nov. \\
\hline Emlös - Mammals & 12 & 18 & 7 & 18 \\
Madár - Birds & 5 & 2 & 2 & 2 \\
Tojás - Eggs & - & 5 & 3 & 1 \\
Hús - Meat & 5 & 7 & 4 & 5 \\
Kétéltü, hüllö - Amphibians, Reptiles & - & 1 & $\mathbf{2}$ & - \\
Hal - Fishes & - & 5 & 1 & 4 \\
Puhatestü - Molluscs & 10 & 5 & 6 & 3 \\
Rovar - Insects & 10 & 21 & 62 & 25 \\
Magvak - Seeds & 32 & 22 & 11 & 33 \\
Zöld növényi részek & 3 & 3 & - & 1 \\
$\quad-$ Green parts of plants & 23 & 11 & 2 & 8 \\
Emészthetetlen anyag - Indigestible pieces & 100 & 100 & 100 & 100 \\
\hline Összesen & & & & \\
\hline
\end{tabular}

A faj közép-európai táplálkozási vizsgálatait FARAGÓ (1991) összefoglalója alapján az alábbiakban adhatjuk meg.

Szlovákiában FERIANC (1979) mindenevőnek tartotta, amely a hústáplálékot előnybe részesíti. Kiemelte az ízeltlábú fogyasztását, de megemlítette halfogyasztó és fészekrabló mivoltát is. Ugyancsak Szlovákiában BRTEK (1971, idézi HUDEC, 1983) 512 teljes emésztőrendszer elemzése alapján 55,6\%-ban állati eredetü, 44,4\%-ban növényi eredetü táplálék összetételt talált. Az állati táplálékból 18,4\% (ennek mintegy fele döghús), származott emlősöktől, 2,7\% kétéltüektől, 2,5\% volt madártojás és 1,4\% madár (ennek ugyancsak mintegy fele döghús volt). Az állati eredetủ táplálék jórészét gerinctelenek tették ki: ízeltlábúak 35,6\%, puhatestüek és férgek 10,0\%. 
2. táblázat: A dolmányos varjú táplálék-összetételének változása az év folyamán, Magyarországon (KOSARAS, 1986)

Table 2: Montly changes in Hooded Crow's diet composition, Hungary (KOSARAS, 1986)

\begin{tabular}{|c|c|c|c|c|c|c|c|c|}
\hline Időszak - Period & \multicolumn{2}{|c|}{ Dec. - Febr. } & \multicolumn{2}{|c|}{ Márc. - Máj. } & \multicolumn{2}{|c|}{ Jún. - Aug. } & \multicolumn{2}{|c|}{ Szept. - Nov. } \\
\hline Mintaszám - Sample & 17 & & 30 & & 26 & & 11 & \\
\hline Táplálék - Diet & $\begin{array}{c}\text { gyakoriság } \\
\text { frequency } \\
\%\end{array}$ & $\begin{array}{c}\text { tömeg } \\
\text { mass } \\
\%\end{array}$ & $\begin{array}{c}\text { gyakoriság } \\
\text { frequency } \\
\%\end{array}$ & $\begin{array}{c}\text { tömeg } \\
\text { mass } \\
\% \\
\end{array}$ & $\begin{array}{c}\text { gyakoriság } \\
\text { frequency } \\
\%\end{array}$ & $\begin{array}{c}\text { tömeg } \\
\text { mass } \\
\%\end{array}$ & $\begin{array}{c}\text { gyakoriság } \\
\text { frequency } \\
\%\end{array}$ & $\begin{array}{c}\text { tömeg } \\
\text { mass } \\
\%\end{array}$ \\
\hline $\begin{array}{l}\text { Haszonmagvak - Seeds } \\
\text { of cultivated plants }\end{array}$ & 39,5 & 73,6 & 2,0 & 0,3 & 16,7 & 43,0 & 22,2 & 52,0 \\
\hline Gyommag - Weed seeds & - & - & - & - & 2,8 & 2,2 & - & - \\
\hline $\begin{array}{l}\text { Egyéb növényi eredetü - } \\
\text { other plant diet }\end{array}$ & 18,4 & 19,6 & 20,0 & 56,2 & 20,6 & 35,5 & 27,8 & 30,3 \\
\hline Annelida, Gastropoda & 18,4 & 3,5 & 12,0 & 2,3 & 21,5 & 1,9 & 5,6 & 0,7 \\
\hline Arthopoda & 2,6 & - & 39,0 & 21,5 & 28,0 & 9,5 & 36,1 & 9,4 \\
\hline Vertebrata & 15,1 & 2,1 & 20,0 & 13,9 & 8,4 & 7,0 & 5,6 & 7,2 \\
\hline Madártojás - Eggs & - & - & 1,0 & 0,4 & - & - & - & - \\
\hline $\begin{array}{l}\text { Egyéb állati eredetü } \\
\text { - other animal diet }\end{array}$ & 5,3 & 1,1 & 6,0 & 5,4 & 1,9 & 0,9 & 2,8 & 0,4 \\
\hline Összesen & 100,0 & 100,0 & 100,0 & 100,0 & 100,0 & 100,0 & 100,0 & 100,0 \\
\hline
\end{tabular}

Csehországból HUDEC (1983) idézte FARSKY (1928) vizsgálatait, aki 468 gyomorból 432-ben talált növényi maradványokat, 324 esetben kultúrnövények hajtásait, 146 esetben, kis mennyiségben gyommagvakat. Az állati eredetü táplálék nemek közül a rovarok és más ízeltlábúak voltak a leggyakoribbak (338 esetben). Puhatestüek 198 esetben, pockok80 esetben szerepeltek tápláléklistáján.

Németországban a XIX. század végén végzett RÖRIG (idézi MELDE, 1984) 3259 dolmányos varjú és kormos varjú gyomortartalom vizsgálatot (akkor e két fajt egy fajnak tartották). RÖRIG a növényi táplálék túlsúlyát $(57,6 \%)$ találta, döntően a termesztett növények majvai alapján. Az állati komponenst 23,9\%-ban adta meg, főként rovar $(8,3 \%)$, pocok $(5,8 \%)$, döghús $(5,0 \%)$, madártojás $(3,1 \%)$ és hal $(1,7 \%)$ fogyasztása alapján.

DECKERT (1980) Kelet-Németországban (az egykori NDK-ban) 134 dolmányos varjú köpete alapján (3. táblázat) főleg az április-júniusi időszakban talált legtöbb esetben ízeltlábúakat, illetve más állatok maradványait. Meglepő viszont a többi - fent említett vizsgálathoz képest a gabona magvak alacsony előfordulási gyakorisága és aránya.

Összefoglalva megállapítható, hogy a dolmányos varjú felnőtt példányai tavaszi és nyári táplálékában az állati hányad jelentős, de nem döntő (19-43\%), nem feltétlenül meghatározóak az ízeltlábúak (9-22\%) (FARAGÓ, 1991) a dolmányos varjú táplálkozási viszonyaiban észlelhető tavaszi ízeltlábú részarány növekedés nem igazolja azok hiányát a mezei ökoszisztémákban. A nyári állati eredetü táplálékcsökkenést, ami egyúttal a haszonnövények magvainak részarány-növekedését mutatja (43\%-os tömegaránnyal) a betakarítási veszteségek következtében fellépő táplálékkínálat által előidézte táplálkozási stratégiaváltásnak tekinthetjük, egyúttal a faj nagyfokú adaptivitására is utal. A táplálékvizsgálatokból - a tojástartalom állaga miatt a fészekalj zsákmányolása csak néhány közlésből igazolható, ugyanakkor más módszer szerinti megfigyelések ezt kétséget kizáróan valós veszélyeztető tényezőként említik. 


\section{3. táblázat: A dolmányos varjú táplálék-összetétele Kelet-Németországban (134 köpet elemzése alapján) (DECKERT, 1980)}

Table 3: Diet composition of Hooded Crow based on 134 pellets, Ost Germany (DECKERT, 1980)

\begin{tabular}{|c|c|c|c|c|c|}
\hline $\begin{array}{c}\text { Táplálék (\%) } \\
\text { Diet (\%) }\end{array}$ & $\begin{array}{l}\text { Nov. - Márc. } \\
\text { Nov. - March }\end{array}$ & $\begin{array}{l}\text { Ápr. } \\
\text { Apr. }\end{array}$ & $\begin{array}{l}\text { Máj. - Jún. } \\
\text { May - June }\end{array}$ & $\begin{array}{l}\text { Júl. - Aug. } \\
\text { July - Aug. }\end{array}$ & $\begin{array}{l}\text { Szept. - Okt. } \\
\text { Sept. - Oct. }\end{array}$ \\
\hline $\begin{array}{l}\text { Gabonamaradvány (fóként rozs) } \\
\text { - Crops (mostly ryes) }\end{array}$ & 15 & 6 & 4 & 4 & 6 \\
\hline Tyúktojáshéj-Hen egg-shell & 36 & 5 & 2 & 4 & 3 \\
\hline Gyümölcs magvak - Fruit pips & 4 & - & - & - & 2 \\
\hline Papír és egyéb - Paper and other rests & 51 & - & - & - & - \\
\hline Gumi - Rubber & 13 & - & - & - & - \\
\hline Salak, cserépdarab - Slag, tile parts & 17 & - & 2 & - & - \\
\hline Napraforgó - Sunflower seeds & 1 & - & - & - & - \\
\hline Mollusca & 17 & 2 & - & 4 & 1 \\
\hline Curculionidae & 3 & 5 & 8 & 1 & - \\
\hline Geotrupinae & 2 & 2 & 4 & - & 3 \\
\hline Elateridae & - & 2 & 2 & 2 & - \\
\hline Egyéb Coleoptera - Other Coleoptera & 10 & - & 1 & - & - \\
\hline Heteroptera & 1 & 3 & 4 & - & 2 \\
\hline Orthoptera & 1 & - & 1 & 2 & 4 \\
\hline Formicoidea & - & - & 2 & - & - \\
\hline Vespidae & 3 & - & - & - & 1 \\
\hline $\begin{array}{l}\text { Egyéb Hymenoptera } \\
\text { - Other Coleoptera }\end{array}$ & - & 1 & - & - & - \\
\hline Halak - Fishes & - & - & 4 & 2 & 1 \\
\hline Cickányok - Shrews & 3 & - & - & 1 & - \\
\hline Pockok - Voles & 5 & - & - & 1 & - \\
\hline Madárfióka - Nestlings & - & - & 1 & - & - \\
\hline $\begin{array}{l}\text { Nagyobb csont töredéke } \\
\text { - Bone fragments }\end{array}$ & 12 & - & - & - & - \\
\hline $\begin{array}{l}\text { Meghatározhatatlan növénymarad- } \\
\text { vány - unidentifiable plant parts }\end{array}$ & 4 & 1 & 2 & - & - \\
\hline Összes köpetszám & 90 & 7 & 14 & 10 & 13 \\
\hline
\end{tabular}

\subsection{ELTERJEDÉS}

Korábban egy Corvus corone szuperfaj tagjaként a Corvus cornix-szal (és esetleg a Corvus pectoralis-sal) együtt tartották nyilván, azok alfajaiként. Egy a Nyugati- és egy a KeletiPalearktiszban előforduló, egységesen fekete tollazattal jellemezhető alfajcsoportot egy másik, a háton és a hason szürke tollazattal jellemezhető alfajcsoport tagolta két részre (GLUTZ VON BLOTZHEIM \& BAUER, 1993).

Fenti rendszer szerint (A) corone alfajcsoportba (kormos varjak) - tehát az egyöntetűen fekete tollazatú madarak közé - tartozott egyrészt a Ny-Európában honos (1) C. corone corone , másrészt a Kelet-Palearktiszban élő (2) C. corone orientalis. A C. c. corone Angliától és Schleswig-Holsteintől D-re, illetve az Elbától nyugatra 
Ausztriáig és a Déli-Alpok olasz területéig, Franciaországig és az Ibériai-félszigetig fordul elő. A C. . orientalis elterjedési területe Szibéria egy részére, Közép-Ázsiára tehető, keleti határa egészen Japánig terjed.

A közöttük élő (B) cornix alfajcsoport (dolmányos varjak) nagyságában és színintenzitásában klinálisan változik. A (3) C. corone cornix Írországban, Észak-Skóciában, Dániában, Észak- és Kelet-Európában az Elbától K-re az Urálig és a Krímig, délen Erdélyig, a Balkán- és az Appennin-félsziget északi területeiig költ. Keleti irányba csatlakozik hozzá az ugyancsak szürke tollú (4) C. corone sharpii Nyugat-Szibériában, a Kaukázusban, Észak- és Közép-Iránban (kevésbé hamvas szürke), valamint Irakban és DNy-Iránban (a csaknem fehér) (5) $C$. corone capellanus. Korzika és Szardínia, Délkelet-Európa, Elö-Ázsia és Egyiptom kisebb testü, vékonyabb csőrü, halványabb tollazatú populációit (6) C. corone sardonius néven ismerték el alfajként. Különböző finomabb színváltozatait, amelyeket korábban alfajként leírtak, már csak földrajzi változatoknak tekintették (GLUTZ VON BLOTZHEIM \& BAUER, 1993). Így tartotta számon egyébként az 1998-as magyar madárnévjegyzék is (MAGYAR et al., 1998)

Ma két elkülönülő fajként tartják nyilván (MADGE, 2016a; 2016b), amelynek tagolása a következö:

- Corvus corone - Kormos varjú - amelynek két alfaja van:

Corvus corone corone

Corvus corone orientalis

- Corvus cornix - Dolmányos varjú - amelynek négy alfaját ismerik el:

Corvus cornix cornix

Corvus cornix sharpii

Corvus cornix pallescens

Corvus cornix capellanus

A két fajra való különítés szerepelt KEVE $(1960 ; 1984)$ névjegyzékeiben, 1960-ban csak a két faj törzsalakjaival, 1984-ben már megjelent a Corvus cornix sardonius, tehát nem a C. corone alfajaként (lásd GLUTZ VON BLOTZHEIM \& BAUER, 1993 fenti beosztása).

A ma érvényes magyar névjegyzék szerint (MME NOMENCLATOR BIZOTTSÁG, 2008) Magyarországon a

- Corvus corone és annak

Corvus corone corone törzsalakja

- Corvus cornix és annak

Corvus cornix cornix törzsalakja, valamint

Corvus cornix sharpii alfaja fordul elö.

Megjegyzendő, hogy a 2008-as névjegyzékben tévesen a Corvus corone sharpii alfajnév szerepel a Corvus cornix fajnév alatt, illetve hogy a C. cornix sharpii alfaj magában foglalja a korábban KEVE (1984) által közölt Corvus cornix sardoniust is, utóbbi tehát annak szinonimája.

Európában tehát 2 faja él (1-2. térkép). Magyarországon a $C$. corone fajból a $C$. corone corone az ország Ny-i területein ritka, rendszertelen fészkelö, a $C$. cornix fajból a $C$. cornix cornix gyakori és széles körben elterjedt, elsősorban a sík- és dombvidékeinken (3-6. térkép), a C. cornix sharpii (korábban sardonius) ritka kóborlóként jelent meg, két hiteles adata: (1) Taktaszada, 1928. december 28. (KeVE, 1972b), (2) Bácsalmás-Sós-tó, 1969. szeptember 19. (RÉKÁsI, 1975b). A C. c. corone és a C. c. orientalis, illetöleg a C. c. cornix és a C. c. sharpii areái Európában mintegy $2100 \mathrm{~km}$, Szibériában és Közép-Ázsiában több mint $3300 \mathrm{~km}$ hosszan érintkeznek, és ezen az ún. hibridizációs vonal mentén kereszteződnek is egymással. A hibridek termékenységéről még kevés bizonyosat tudunk (GLUTZ VON BLOTZHEIM \& BAUER, 1993). A hibridizációs vonal Nyugat-Magyarországon a Hegyeshalom-Iván-IkervárKörmend-Csákánydoroszló-Ivánc településekkel kitüzhetően húzódik (CsABA, 1963), de a dolmányos varjú tollszínezetében a másik alfaj még körülbelül a Balaton vonaláig érezteti hatását (KEVE, 1972). A déli alfaj (C. c. sharpii syn. sardonius) világosabb színe viszont DélMagyarországon észlelhető a Lovászi - Baláta - Sellye - Vajszló - Bácsszentgyörgy Zsombó - Szeged vonalig (KEVE, 1972). 

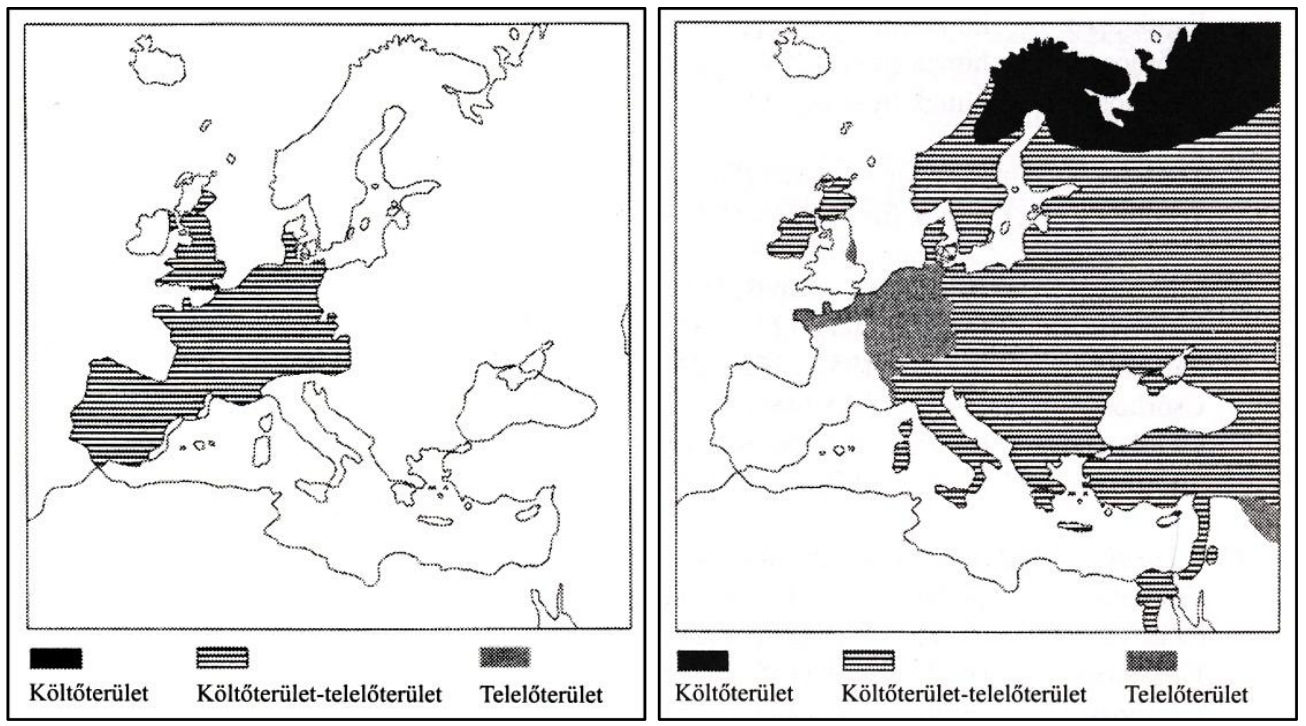

1. térkép: A kormos varjú és dolmányos varjú elterjedése Európában (JONSSON, 1993) Map 1: Distribution of Carrion Crow and Hooded Crow in Europe (JONSSON, 1993)

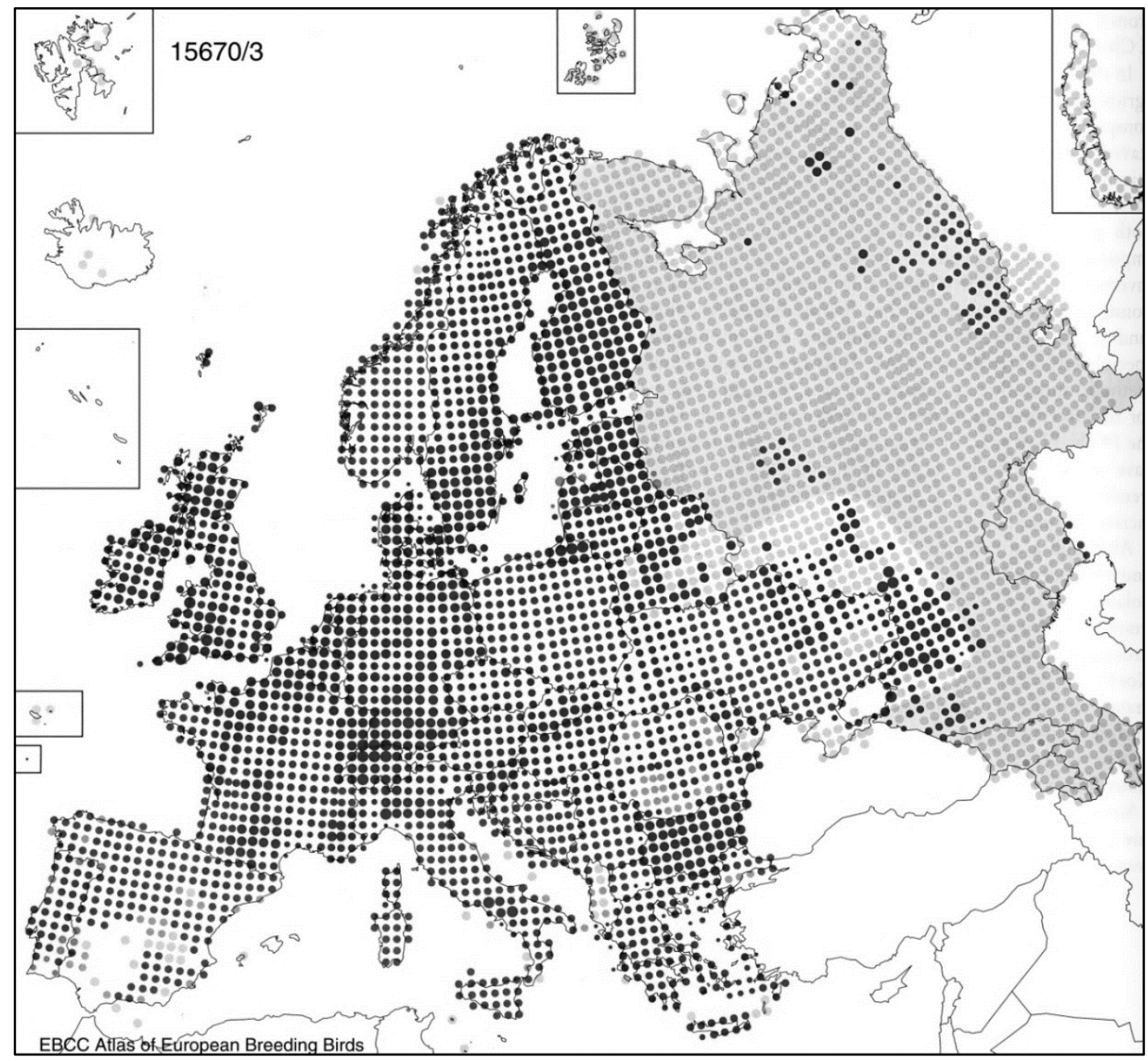

2. térkép: A kormos varjú és a dolmányos varjú elterjedése Európában (HOUSTON, 1997) Map 2: Distribution of Carrion Crow and Hooded Crow in Europe (HOUSTON, 1997) 


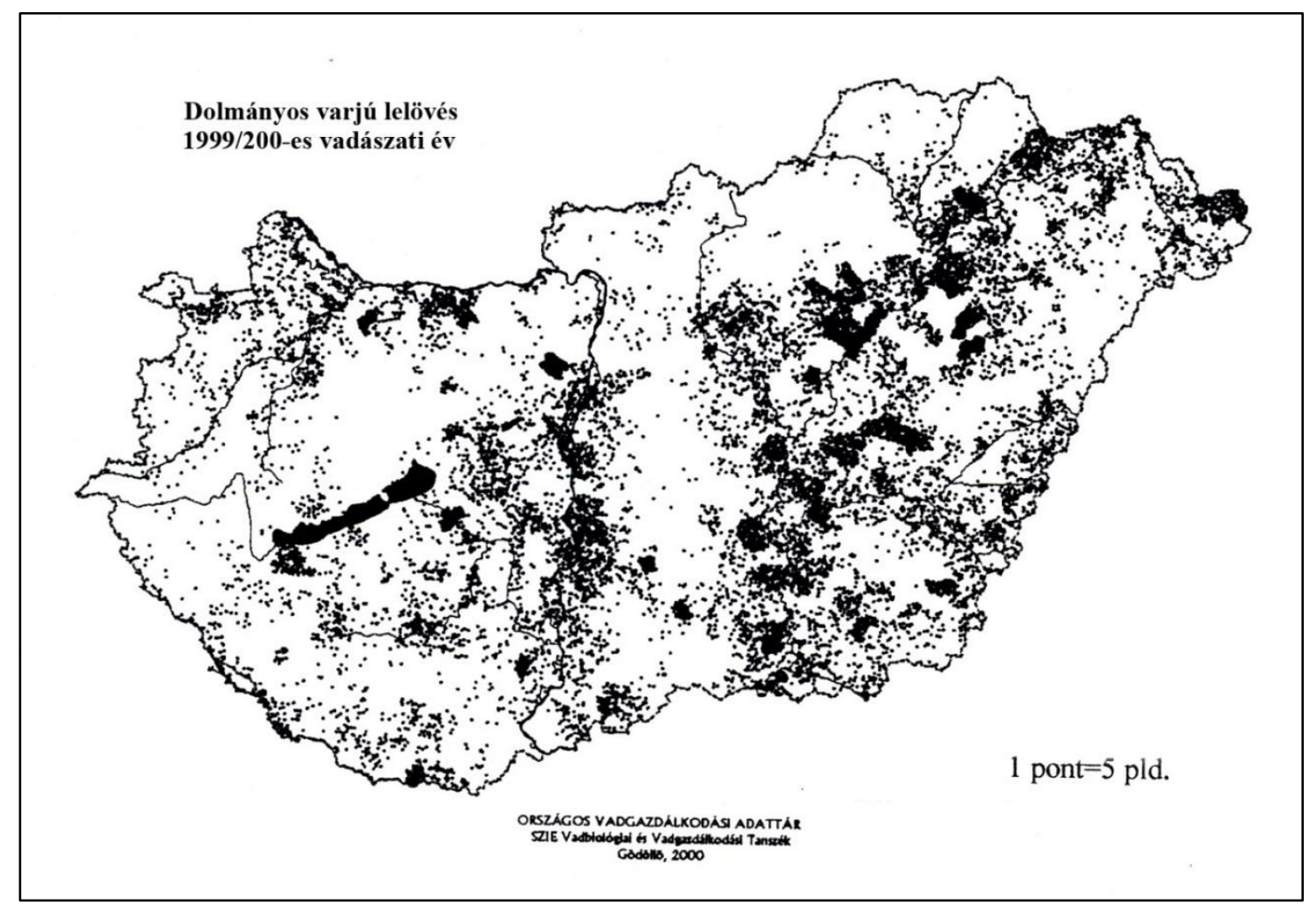

3. térkép: A dolmányos varjú terítékének eloszlása Magyarországon az 1999/2000-es vadászati évben (ORSZÁGOS VADGAZDÁLKODÁSI ADATTÁR alapján)

Map 3: Distribution of Hooded Crow (after bags) in Hungary, in 1999/2000 (based on the NATIONAL GAME MANAGEMENT DATABASE)

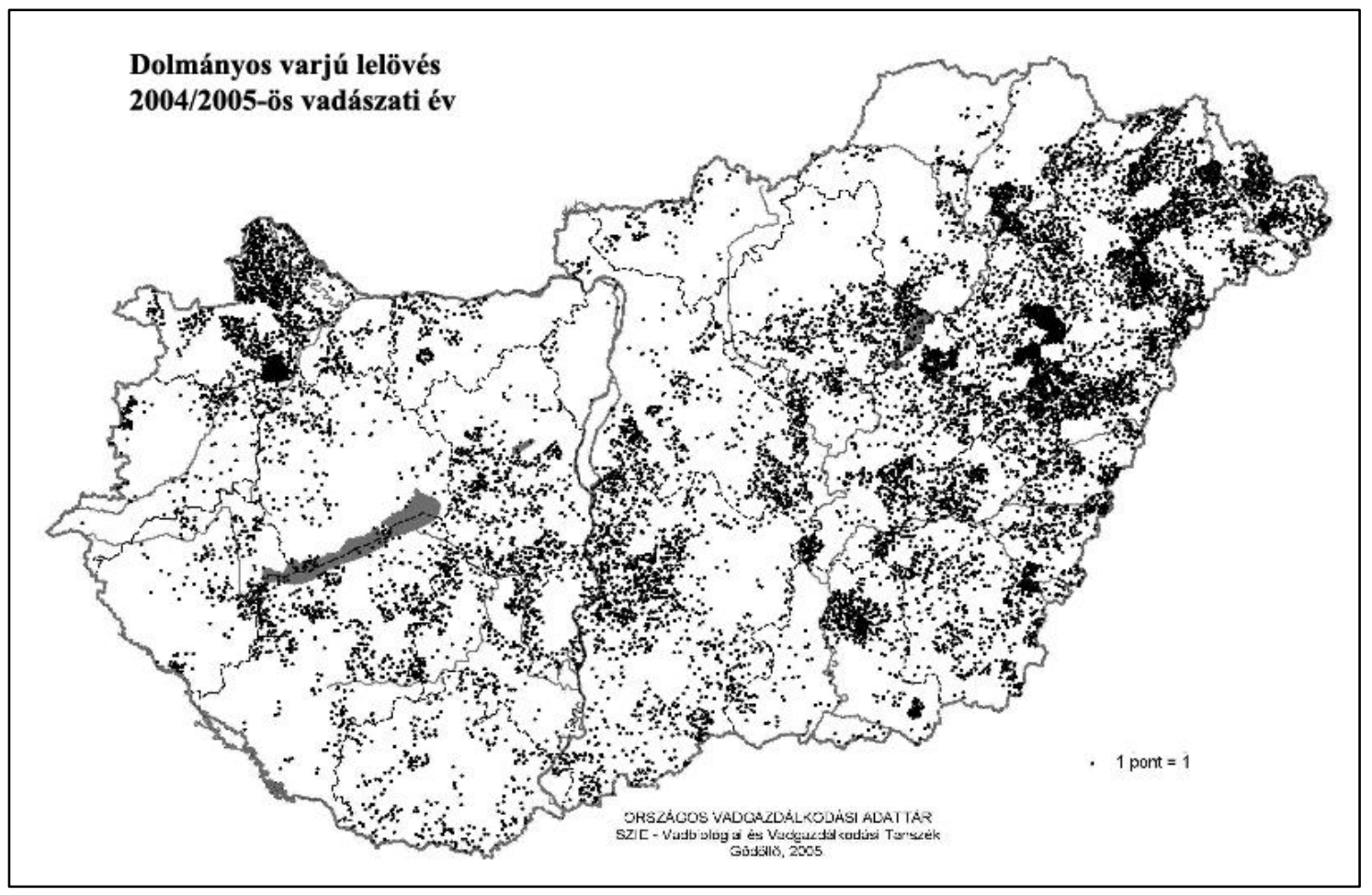

4. térkép: A dolmányos varjú terítékének eloszlása Magyarországon a 2004/2005-ös vadászati évben (ORSZÁGOS VADGAZDÁLKODÁSI AdATTÁR alapján)

Map 4: Distribution of Hooded Crow (after bags) in Hungary, in 2004/2005 (based on the NATIONAL GAME MANAGEMENT DATABASE) 


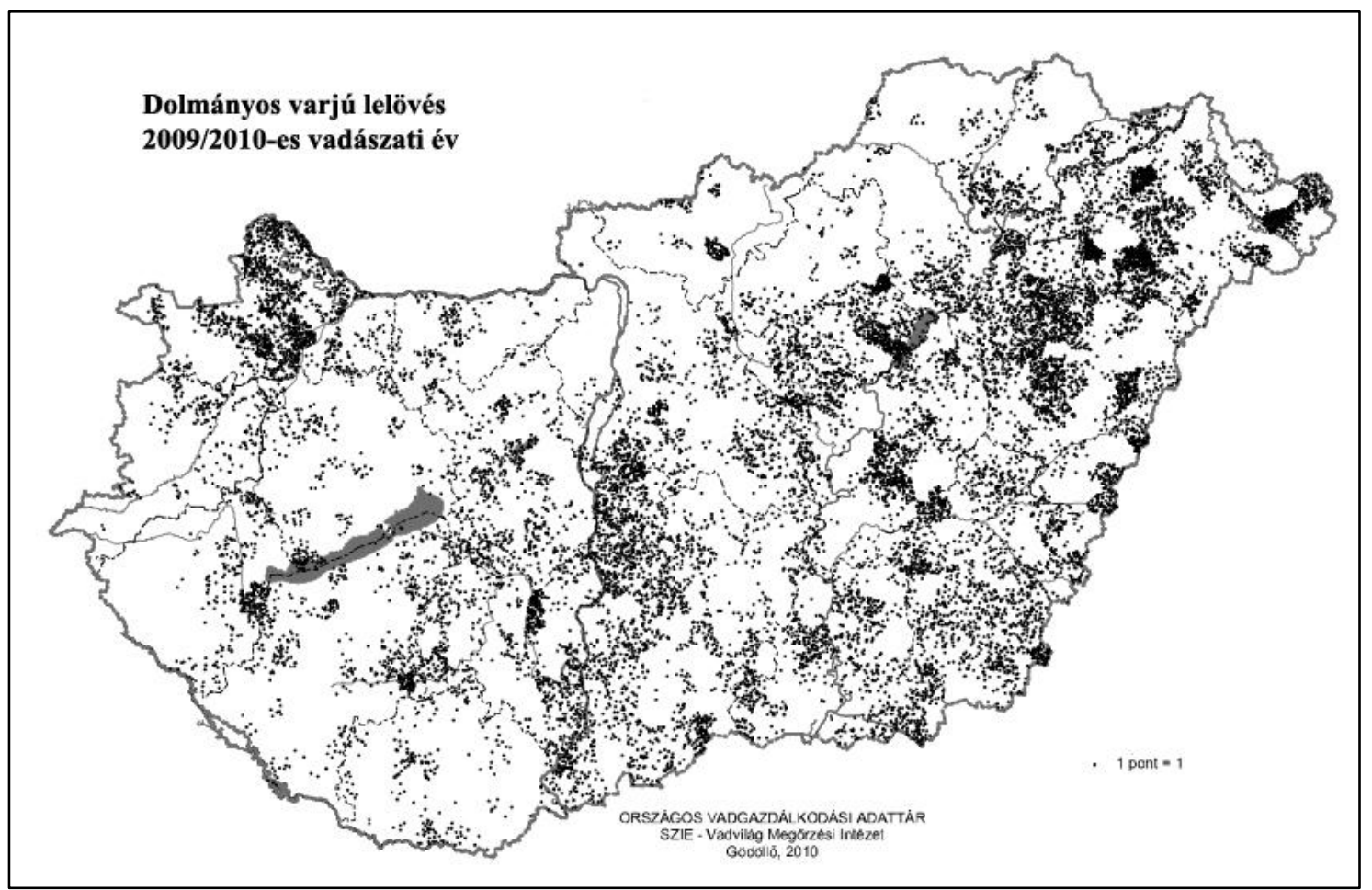

5. térkép: A dolmányos varjú terítékének eloszlása Magyarországon a 2009/2010-es vadászati évben (ORSZÁGOS VADGAZDÁLKODÁSI ADATTÁR alapján)

Map 5: Distribution of Hooded Crow (after bags) in Hungary, in 2009/2010 (based on the NATIONAL GAME MANAGEMENT DATABASE)

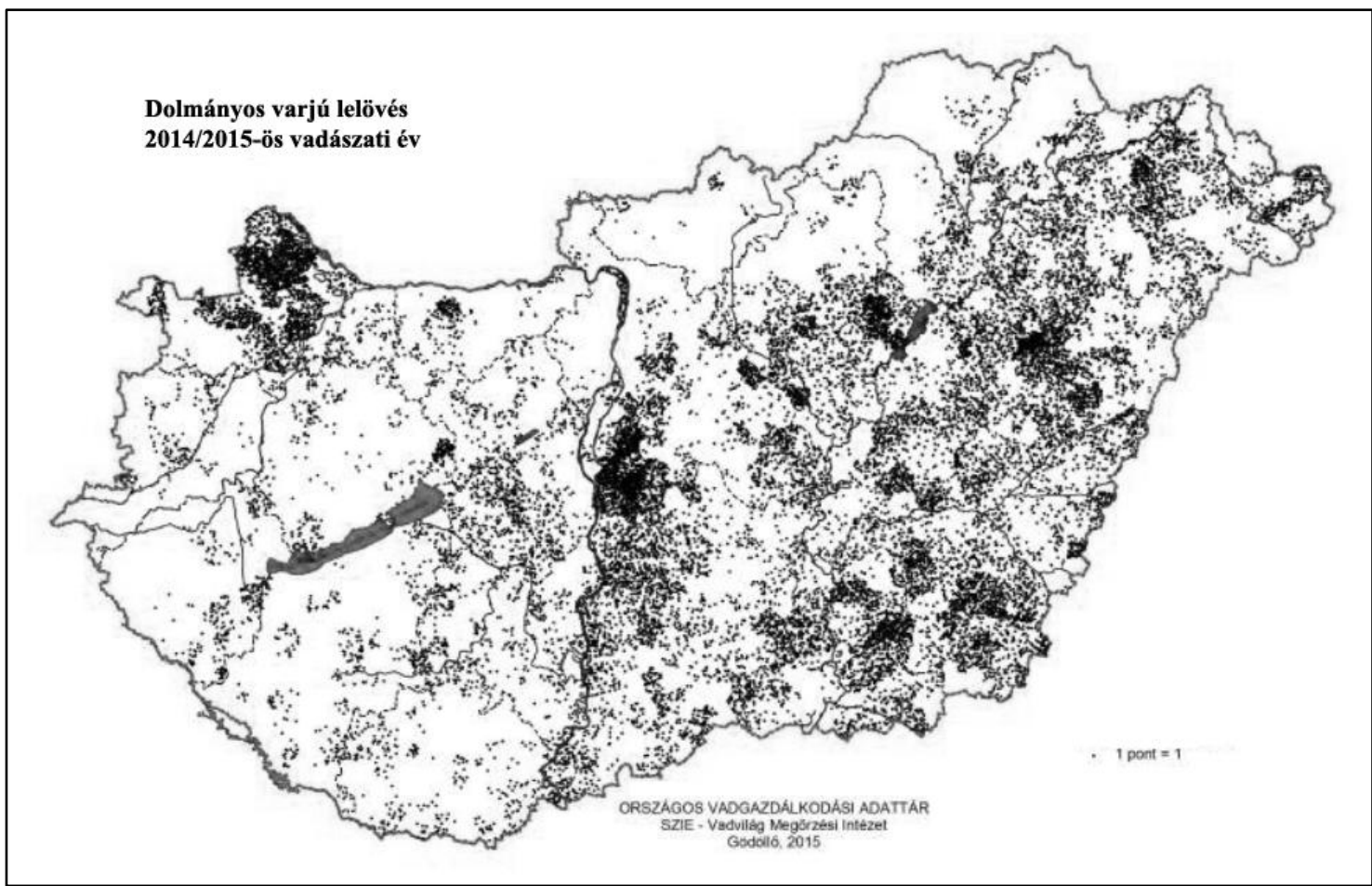

6. térkép: A dolmányos varjú terítékének eloszlása Magyarországon a 2014/2015-ös vadászati évben (ORSZÁGOS VADGAZDÁLKODÁSI ADATTÁR alapján)

Map 6: Distribution of Hooded Crow (after bags) in Hungary, in 2014/2015 (based on the NATIONAL GAME MANAGEMENT DATABASE) 


\subsection{VÁNDORLÁS ÉS TELELÉS}

Közép-Európában állandó madár, csak költési időszak után figyelhető meg 10-20 km-es migrációja, néha összeverődve, olykor vetési varjakhoz csatlakozva. A Skandináviában fészkelők a tengerpart mentén DNy-i irányba, a tőlünk K-re fészkelők D-DNy-i irányba vonulhatnak. Egyetlen hazai gyürüs madár került meg külföldön, 16 km-re a határtól; 1949ben Sopronnál jelölték, s még abban az évben a Fertő keleti partjánál, llmitzben (Ausztria) került kézre. Egy Eszéken (Horvátország) jelölt madár Beremenden $(\rightarrow 38 \mathrm{~km})$, egy Zombornál (Szerbia) jelölt példány pedig 4 év után Baján $(\rightarrow 48 \mathrm{~km})$ került meg (FARAGÓ, 2001b; BANKOVICS \& VADÁSZ, 2009).

\section{5. ÁllománYNAgYSÁG}

Európában stabil (S) állományú faj (TUCKER \& HEATH, 1994). Összes európai állományát az 1990-es években $5715000-6986000$ példányra, oroszországi állományát 1000 00010000000 példányra, a török populációt 100 000-1 000000 példányra becsülték (HUOSTON, 1997). A C. corone faj európai állományát az ezredfordulón 6100 000-20 000000 párban adták meg (BIRDLIFE INTERNATIONAL/EUROPEAN BIRD CENSUS COUNCIL, 2000), négy évvel később pedig 7000 000-17 000000 párnak (BIRDLIFE INTERNATIONAL, 2004) (4. táblázat; 7. térkép).

Magyarországon az 1984. évi országos felmérés alapján a fészkelő állomány mintegy 49500 pár volt, 0,52 pld/ $\mathrm{km}^{2}$ állománysürüséggel (KALOTÁs, 1988). Az 1990-es években mintegy 70 000-80 000 pár fészkelhetett országunkban (MAGYAR et al., 1998). A 2000-es évek elején a kormos varjú (Corvus corone) fészkelő állományát 20-50 párra, a dolmányos varjúét (Corvus cornix) pedig 51000-84000 párra becsülték (MME NOMENCLATOR BiZOTTSÁG, 2008).

A vadászati statisztika alakulása támpontot szolgáltathat az állományváltozáshoz. A vadlelövési statisztikák szerint az 1970-es években 80000 pld-t lőttek évente. Kiemelkedett 1974, amikor 131000 pld esett. Az 1980-as évek elején 60 000-65 000 pld volt az évi teríték, 1990-ben azonban már csak 48 000, az ezredfordulón 20000 példány alá csökkent úgy hogy 2006-ban 14000 példányos minimummal érte el legalacsonyabb értékét. A 2010-es években újra megközelítette a 20000 példányt, 2014-ben pedig már 23260 példány esett.

Az Országos Vadgazdálkodási Adattárban 2004-2015 viszonylatában rendelkezésre állnak a dolmányos varjú megyénkénti, vadgazdálkodók által becsült fészkelő állománya (5. táblázat). Az értékeket (maximum 2015: 99915 pld azaz mintegy 50000 pár összevetve a terítékadatokkal, illetve az MME NOMENCLATOR BIZOTTSÁG (2008) adataival (51 000 - 84000 fészkelő pár), azt erösen alulbecsültnek kell tekintenünk.

\subsection{TERMÉSZETES KORLÁTOZÓ TÉNYEZŐK}

\subsubsection{A populáció sürüségét befolyásoló elsődleges paraméterek}

A természetes populációsürüséget a termékenység, a halandóság illetőleg a be-és elvándorlás határozza meg a dolmányos varjú esetében is. A vadgazda feladata - mivel dúvad fajról van szó -, hogy a termékenység növekedését elősegítő faktorokat gyengítse, a halandóságot növelöket pedig a faj megtartása mellett erősítse. Az állománynövelő bevándorlást szabályozott keretek között folytatott dúvadgazdálkodás segítségével lehet kontrollálni. 
4. táblázat: A dolmányos varjú állományok nagysága Európa országaiban (BIRDLIFE INTERNATIONAL, 2004)

Table 4: Hooded Crow populations in European countries (BIRDLIFE INTERNATIONAL, 2004)

\begin{tabular}{|c|c|c|c|c|}
\hline $\begin{array}{l}\text { Ország } \\
\text { Country }\end{array}$ & $\begin{array}{l}\text { Fészkelő állomány (pár) } \\
\text { Breeding pop. Size (pairs) }\end{array}$ & $\begin{array}{l}\text { Év(ek) } \\
\operatorname{Year}(s)\end{array}$ & $\begin{array}{l}\text { Trend } \\
\text { Trend }\end{array}$ & Mag. \% \\
\hline Albania & $10,000-30,000$ & 02 & $(+)$ & $(0-19)$ \\
\hline Andorra & $(100-200)$ & 99-01 & (0) & $(0-19)$ \\
\hline Armenia & $10,000-15,000$ & $01-02$ & + & $0-9$ \\
\hline Austria & $(40,000-80,000)$ & $98-02$ & (0) & $(0-19)$ \\
\hline Azerbaijan & $(2,000-20,000)$ & $96-00$ & (0) & $(0-19)$ \\
\hline Belarus & $280,000-320,000$ & $97-02$ & $(0)$ & $(0-19)$ \\
\hline Belgium & $20,000-100,000$ & $01-02$ & $(0)$ & $(0-19)$ \\
\hline Bosnia \& HG & $(20,000-50,000)$ & $90-00$ & $(0)$ & $(0-19)$ \\
\hline Bulgaria & $50,000-120,000$ & $96-02$ & 0 & $0-9$ \\
\hline Croatia & $(40,000-50,000)$ & 02 & $(-)$ & $(>80)$ \\
\hline Cyprus & $(20,000-60,000)$ & $94-02$ & $(+)$ & $(10-19)$ \\
\hline Czech Rep. & $12,000-24,000$ & 00 & 0 & $0-19$ \\
\hline Denmark & $(150,000-300,000)$ & 00 & + & $10-19$ \\
\hline Faroe Is & $1,500-1,500$ & 95 & $(0)$ & $(0-19)$ \\
\hline Estonia & $(50,000-100,000)$ & 98 & 0 & $0-19$ \\
\hline Finland & $160,000-230,000$ & $98-02$ & - & 20 \\
\hline France & $(800,000-3,200,000)$ & $98-02$ & - & 9 \\
\hline Georgia & Present & 03 & ? & - \\
\hline Germany & $300,000-600,000$ & $95-99$ & + & $0-19$ \\
\hline Greece & $(50,000-100,000)$ & $95-00$ & $(+)$ & $(0-19)$ \\
\hline Hungary & $51,000-84,000$ & 99-02 & + & $20-49$ \\
\hline Rep. Ireland & $100,000-250,000$ & 88-91 & 0 & $0-19$ \\
\hline Italy & $(110,000-520,000)$ & 03 & $(0)$ & $(0-19)$ \\
\hline Latvia & $20,000-60,000$ & $90-00$ & $(0)$ & $(0-19)$ \\
\hline Liechtenstein & $40-80$ & $98-00$ & 0 & $0-19$ \\
\hline Lithuania & $(50,000-70,000)$ & 99-01 & $(0)$ & $(0-19)$ \\
\hline Luxembourg & $3,000-4,000$ & 02 & 0 & $0-19$ \\
\hline Macedonia & $(20,000-50,000)$ & $90-00$ & $(+)$ & $(20-29)$ \\
\hline Moldova & $8,000-8,500$ & $90-00$ & 0 & $1-19$ \\
\hline Netherlands & $70,000-100,000$ & $98-00$ & + & 33 \\
\hline Norway & $(200,000-700,000)$ & $95-02$ & + & $0-19$ \\
\hline Poland & $50,000-150,000$ & $00-02$ & $(-)$ & $(0-19)$ \\
\hline Partugal & $(5,000-50,000)$ & 02 & $(0)$ & $(0-19)$ \\
\hline Romania & $240,000-320,000$ & $98-02$ & + & $0-19$ \\
\hline Russia & $(1,500,000-5,000,000)$ & $90-00$ & $?$ & - \\
\hline Serbia \& MN & $160,000-250,000$ & $90-02$ & + & $0-9$ \\
\hline Slovakia & $8,000-15,000$ & 80-99 & - & $30-49$ \\
\hline Slovenia & $10-50$ & 94 & $(0)$ & $(0-19)$ \\
\hline Spain & $(310,000-530,000)$ & 92 & $?$ & - \\
\hline Sweden & $240,000-500,000$ & $99-00$ & - & 7 \\
\hline Switzerland & $80,000-150,000$ & $93-96$ & + & $10-19$ \\
\hline Turkey & $(500,000-1,500,000)$ & 01 & $(0)$ & $(0-19)$ \\
\hline Ukraine & $(95,000-130,000)$ & $90-00$ & - & $20-29$ \\
\hline UK & $1,202,000-1.202 .000$ & 00 & + & 25 \\
\hline Össz. - Total & $7,500000-17,000,000$ & \multicolumn{2}{|c|}{ Trend: stabil - stable } & $25-49$ \\
\hline
\end{tabular}




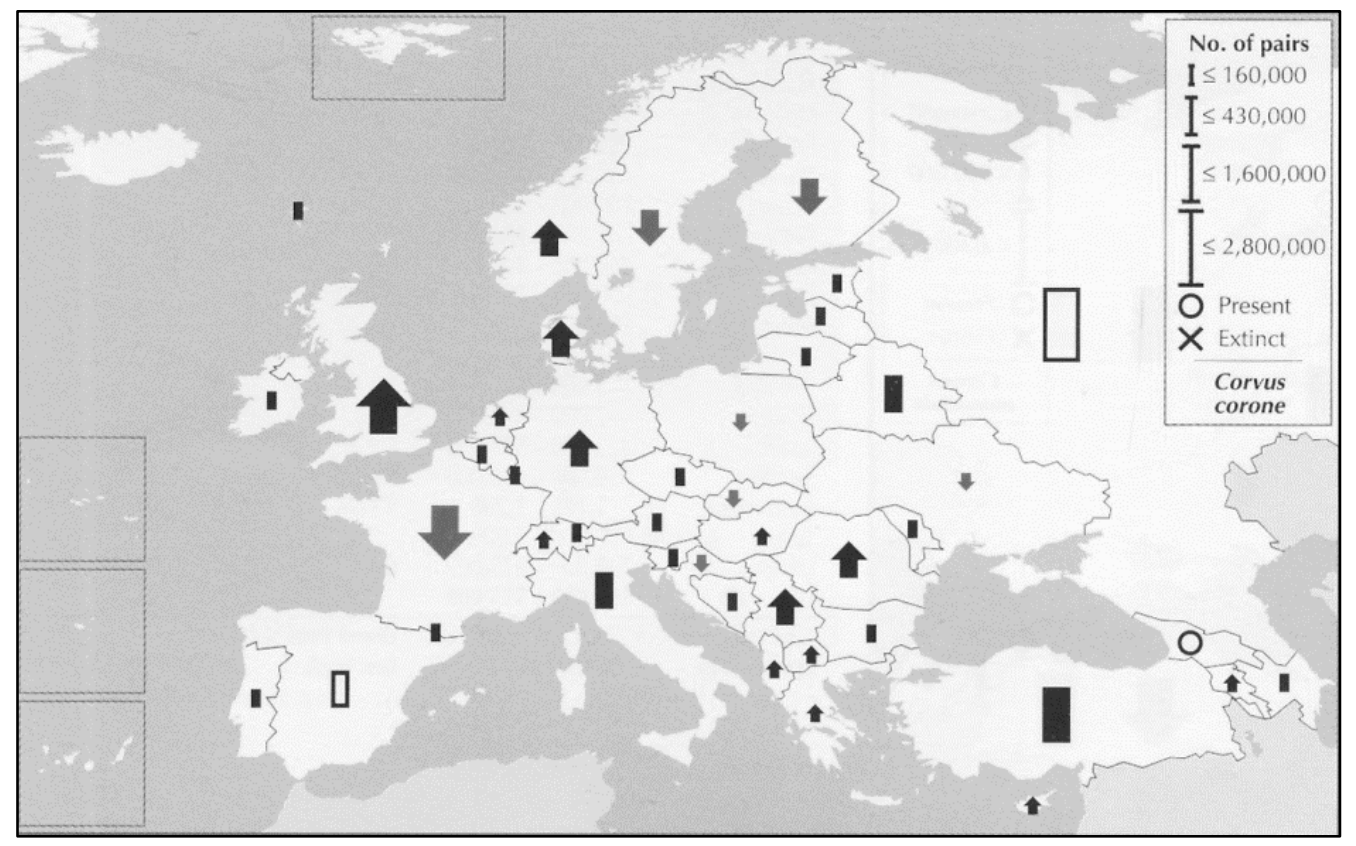

7. térkép: A dolmányos varjú állományok dinamikája Európa egyes országaiban (BIRDLIFE INTERNATIONAL, 2004)

Map 7: Hooded Crow population dynamics in European countries (BIRDLIFE INTERNATIONAL, 2004)

5. táblázat: A dolmányos varjú megyei állománybecslési adatai az ORSZÁGOS VADGAZDÁLKODÁSI AdATTÁR alapján

Table 5: Hooded Crow population estimates in Hungarian counties (based on the NATIONAL GAME MANAGEMENT DATABASE)

\begin{tabular}{|c|c|c|c|c|c|c|c|c|c|c|c|c|}
\hline & 2004 & 005 & 2006 & 007 & 008 & 2009 & 2010 & 2011 & 2012 & 013 & 014 & 2015 \\
\hline Baranya & 58 & 400 & 148 & 342 & 382 & 346 & 2578 & 2430 & 2812 & 319 & 649 & 3578 \\
\hline Bács & 97 & 57 & 72 & 477 & 56 & 59 & 8993 & 8772 & 30 & 32 & 496 & 10256 \\
\hline Béké & 93 & 551 & 377 & 222 & 300 & 549 & 915 & 7117 & 7389 & 7938 & 843 & 7698 \\
\hline $\begin{array}{l}\text { Bors } \\
\text { Zem }\end{array}$ & 2542 & 2544 & 2626 & 2612 & 3091 & 3253 & 3652 & 3417 & 3710 & 3998 & 4188 & 4097 \\
\hline so & 84 & 2246 & 595 & 2535 & 3139 & 3422 & 3249 & 3482 & 3787 & 4066 & 4116 & 4579 \\
\hline Fejé & 90 & 3215 & 420 & 4208 & 4209 & 4691 & 4493 & 4573 & 4926 & 5332 & 5375 & 5818 \\
\hline Soprol & 4613 & 4890 & 724 & 5101 & 6128 & 6319 & 6564 & 6465 & 6206 & 6451 & 6621 & 64 \\
\hline & 99 & 661 & 402 & 174 & 6033 & 6548 & 6868 & 6396 & 7304 & 6931 & 6796 & 7533 \\
\hline & 1326 & 1681 & 1396 & 1675 & 1790 & 1723 & 1846 & 1687 & 2252 & 2145 & 2235 & 2510 \\
\hline & 1279 & 1404 & 372 & 1391 & 1347 & 1443 & 1563 & 1582 & 494 & 1812 & 1856 & 2118 \\
\hline & & & & & & & & & & & & 066 \\
\hline & 78 & 16 & 54 & 95 & 3620 & 713 & 219 & 386 & 5369 & 464 & 9912 & 5873 \\
\hline & 081 & 3661 & 196 & 5029 & 5857 & 5903 & 565 & 6106 & 6152 & 6952 & 6790 & 656 \\
\hline $\mathrm{S}$ & 5526 & 5773 & 6338 & 6946 & 7 & 7 & 6977 & 01 & 21 & 19 & 48 & 7708 \\
\hline gykun- & 218 & 38 & 4034 & 4 & 52 & 4836 & 8 & 35 & 0 & 25 & 6726 & 736 \\
\hline & & & & & & 40 & 98 & 25 & 718 & 270 & 505 & 06 \\
\hline & 18 & 49 & 0 & 211 & 2193 & 2278 & 2513 & 2577 & 2504 & 510 & 656 & 2676 \\
\hline & 62 & 24 & 58 & 3 & 3414 & 3791 & 4277 & 3571 & 3787 & 825 & 4256 & 4536 \\
\hline & 83 & 1904 & 1810 & 2407 & 2395 & 2992 & 3282 & 3311 & 3525 & 3727 & 3780 & 4287 \\
\hline $\begin{array}{l}\text { Mag } \\
\text { össz }\end{array}$ & & & $r=40$ & & & & & & & & & \\
\hline
\end{tabular}


A termékenységet

(1) a mezőgazdasági technológiák károkozásának mértéke,

(2) a táplálékforrás (állati, növényi) mennyisége és minősége, illetőleg

(3) a fészkelőhelyek hiánya korlátozza.

Az ezzel összefüggő halandóságot

(1) a táplálékforrás mennyisége és minősége

(2) a dúvadszabályozás és

(3) az agrotechnológiák határozzák meg.

\subsubsection{A populáció sürüségét befolyásoló környezeti tényezők}

A dolmányos varjú - mint azt az 1.2.1. fejezetben láttuk - maga is tagja annak a bonyolult mezei környezeti rendszernek, mint az szárnyas apróvad fajainkról (fácán, fogoly, mezei nyúl) ismeretes. A dolmányos varjú Magyarországon napjainkban döntően mezőgazdasági (szántó) környezetben, s kisebb arányban városi/települési környezetben él. Hazai elterjedése - amelyet terítékének megoszlásával (3-6. térkép) igazolhatunk leginkább egyértelmúen ezt mutatta.

Az agrár-környezetben élő populációk állománysürüségét általában a populáció 4 elsődleges paraméterén keresztül az élőhely szerkezete, a táplálékforrás kínálata, a mezőgazdasági technológiai folyamatok, az időjárási tényezők és a predáció határozzák meg. A dolmányos varjú, mint predátor faj esetében a zsákmányolás korlátos, lényegében eltekinthetünk tőle.

A faj fészkelőhely (általában élőhely) választásának ökológiai motivációi az alábbiak:

1. Az élettér szerkezete még viszonylag nagytáblás növénytermesztés mellett is, egész évben biztosítja a dolmányos varjú életfeltételeit.

2. A legfontosabb a dolmányos varjú fészkelésére alkalmas élöhelyek - fasorok, facsoportok, erdösávok, erdőszegélyek - növényállományainak vertikális szerkezete megfelelö fészkelő helyet biztosít.

3. Az agrár-élöhelyek, a fészkelés és a fiókanevelés során megfelelő mennyiségben és minőségben kínálják az állati eredetü táplálékot (lásd 1.2.3. fejezet)

4. Az eltérő vetésidejü, tenyészidőszakú, s így különböző betakarítási idejü termesztett növénykultúrák táplálékkínálata részben kiegészíti, részben helyettesíti a visszaszoruló, vagy betakarított növények kínálta táplálékforrást, így a teljes vegetációs időszak kielégíti mind a felnőtt madarak, mind a fiókák állati és növényi eredetü táplálék szükségletét.

\subsubsection{A vadászat hatása}

A dolmányos varjú terítéke - bizonyosan nagyobb állománynagyság mellett - az 1970-es évek elején 65000 példányról 1973-ra 95600 példányra nőtt. Ezt követően egészen 2006-ig folyamatosan csökkent a statisztikákban kimutatott éves lelött mennyisége. A jelenség hasonlóan játszódott le, mint a szarka esetében - azonban magyarázatra is szorul, ugyanis az 1970-es évek második felében kezdték kiterjedten használni a 3-kloro-4-metilanilinhidroklorid hatóanyaggal preparált ún. F-2-es tojásokat, amelyek a varjúfélékre szuperszelektív hatással bírva gyérítették az állományokat. A szer hatásmechanizmusából fakadóan (az állatok ismeretlen helyen, a felvétel után néhány nappal pusztultak el), az elpusztult madarak nem kerültek be a statisztikákba, illetőleg a hatására erőteljesen csökkent 
populációból hagyományos fegyveres gyérítéssel csak csökkenő mennyiségben lehetett terítékre hozni.

Az igazsághoz az is hozzátartozik, hogy a rendszerváltoztatás után az új vadászterületeken az apróvadgazdálkodás, benne a dúvadszabályozás hatékonysága meg sem közelítette az 1970-es évek gyakorlatát.

Mindehhez hozzájárult az is, hogy a fent említett szer amerikai licence lejárt, illetve EU-s tagságunkkal más engedélyeztetési eljárások léptek életbe. A gyártás korszerü kapacitása is nagy összegeket venne igénybe. Mindezen technikai-jogi korlátok mellett a holló (Corvus corax) elterjedési területének és állománysürüségének növekedése - amelyre ugyancsak letális a szer -alkalmazhatósági kiterjedését is erősen beszükítette.

Terítékdinamikája az utóbbi években a következőképpen alakult - 1995: 33805 pld, 2000: 22400 pld, 2005: 15096 pld, 2010: 15029 pld, 2011: 19262 pld, 2012: 19627 pld, 2013: 19581 pld, 2014: 23260 pld (CSÁNYI, 1999, 2001; 2005; 2015; CSÁNYI et al., 2005; 2010; 2012a; 2012b; 2014) (1. ábra), amelynek megyei szintü megoszlását a 6. táblázat mutatja. A teríték csökkenésével együtt járt az állomány-növekedés.

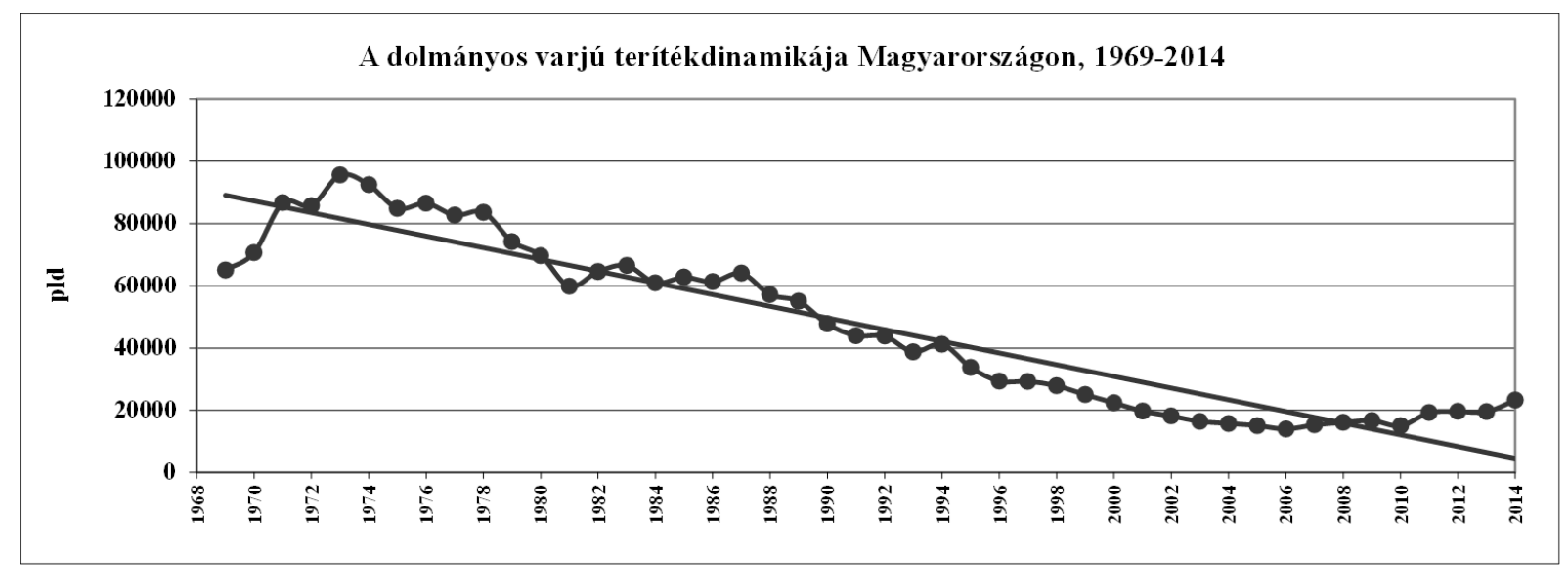

1. ábra: A dolmányos varjú teríték alakulása 1969-2014 között Magyarországon (ORSZÁGOS VADGAZDÁLKODÁSI ADATTÁR alapján)

Figure 1: Hooded Crow bags between 1969 and 2014 in Hungary (based on the NATIONAL GAME MANAGEMENT DATABASE)

\subsubsection{A dolmányos varjú állományt szabályozó tényezők összefoglalása}

A dolmányos varjú állományt - mint láttuk - a fészkelöhelyek megléte, vagy hiánya, a táplálék mennyisége, a betelepülések mértéke és a vadászati szabályozás hatékonysága befolyásolhatják.

Paradoxon, hogy mindazon a fás formációk, amelyek kedvezőek a fácán és a fogoly megtartása, védelme szempontjából, fészkelőhelyet biztosítanak fészek-predátoraiknak, tehát a dolmányos varjúnak is. Az élete nagy részében állat-, sőt ízeltlábú fogyasztó faj táplálékforrása ugyanolyan mértékben biztosított, mint a szárnyas apróvad esetében.

$\mathrm{Az}$ apróvadas élöhely-védelem és élőhely fejlesztés - a bölcs hasznosítás folyományaként - a fészkelőhely és táplálékforrás biztosítása révén, egyúttal a dolmányos varjú populáció megsegítését is jelenti. Éppen ezért az apróvadgazdálkodás semmivel sem helyettesíthető, kiemelt fontosságú része a dúvad-szabályozás/gazdálkodás, benne a dolmányos varjú állomány szabályozása, immár megkettőzött súllyal és hangsúllyal. 


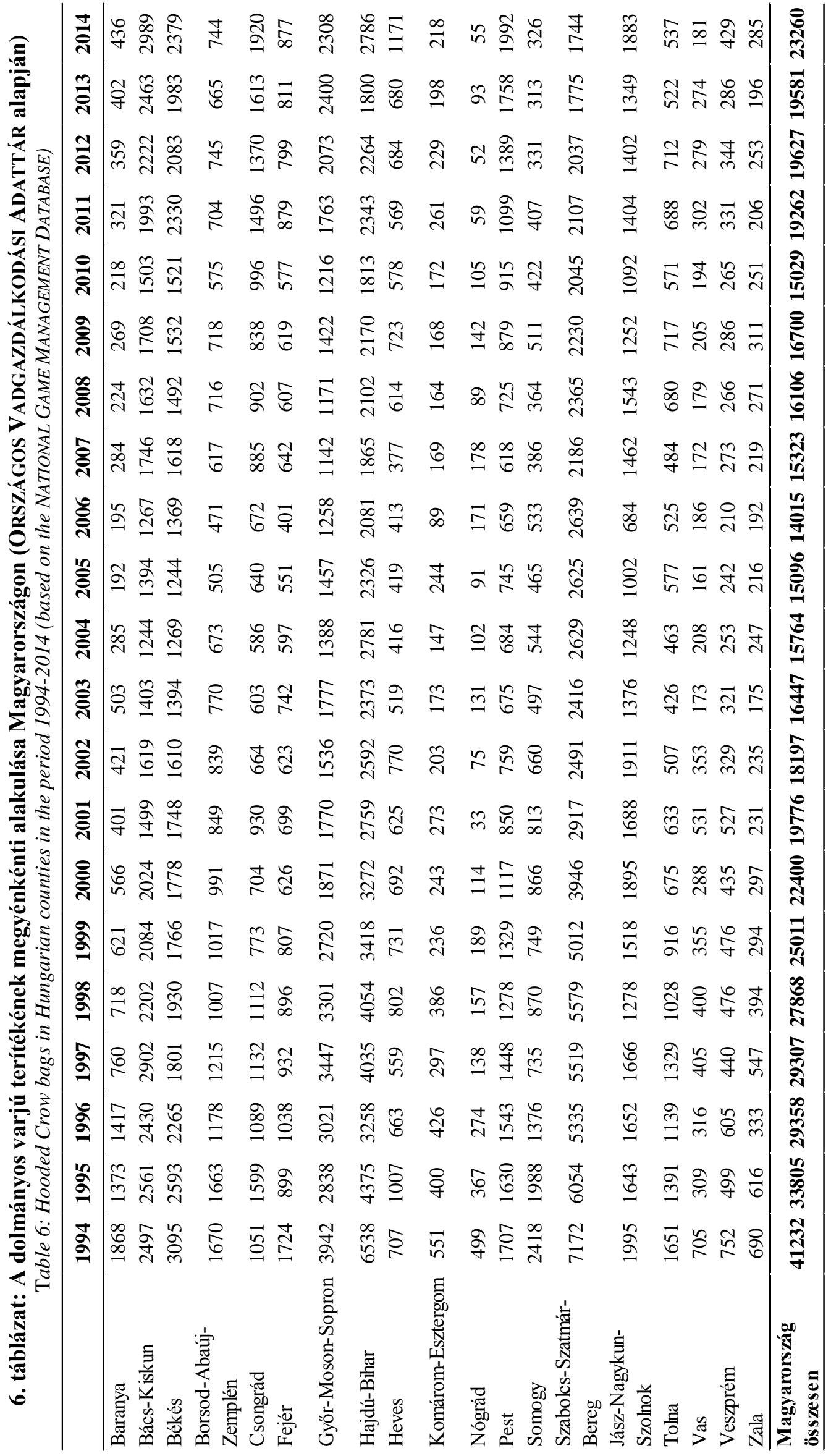




\subsection{A VADÁSZATI SZABÁLYOZÁSI GYAKORLAT ÉRTÉKELÉSE}

A dolmányos varjú korábban egész évben vadászható volt Magyarországon, amit az EU madárvédelmi irányelv - fészkelő populáció védelme - alapján július 1. - február 28(29). közti időszakra kellett módosítani. E változás következményei beláthatatlanok lennének mind a vadgazdálkodás, mind a természetvédelem számára - a faj madárfészekben okozott kártétele miatt -, de a vadászati rendelet, apróvadas vadászterületeken, az apróvad szaporodási időszakában, a vadászati hatóság külön engedélyéhez kötve lehetővé teszi gyérítését. E lehetőséggel a vadgazdálkodóknak szinte kötelezően élniük kell.

Mivel nem vonuló madár, azért állományszabályozását télen is lehet végezni, amit lehetővé is tesz a február 28(29)-ig tartó vadászati idénye.

A szaporodási időszakban végzendő, tulajdonképpen fészkelő-állomány szabályozás alapfeltétele a fészkek helyének ismerete, azaz fészekkataszter és fészektérkép készítése (2. ábra). Ez sajnálatosan a magyar apróvadas vadászterületeken nem gyakorlat. Ennek ismeretében lehet akár a fészkeknél való fegyveres szabályozást, akár csapdázást elvégezni. Tavasszal - a fészkek környékén - elsősorban a LARSEN-csapda különböző változatainak, valamint a TROLLE-LJUNGBY L84 csapdának a használata eredményes (HAJAS, 2007; 2011; 2012) - ezért kell ismerni a lakott fészkek helyét.

Nyár derekától tél végéig terjedő időszakban eredményesebb a létrás- és varsás varjúcsapdák alkalmazása.

Minden csapdatípus sikeres alkalmazásának a kulcsa - a vonatkozó szabályok betartása mellett - az élő csaliállat használata. TAPPER et al. (1991) felmérése szerint a LARSEN-csapdák élő csalival 10-15-ször hatékonyabbak. (A csalimadarak következő szezonra történő eltárolásával és átteleltetésével szemben, jóval költségkímélőbb és egyszerübb alternatíva az új szezon elején, jól álcázható csapóhálók használatával új csalimadarak befogása).

A varjúfélék, így a dolmányos varjú vadászatára - klasszikus módszerekként - a fészekről való ugrasztás, a dögön való vadászat, esti beszállóhelyen történő vadászat, illetve a műuhu alkalmazása kínálkozik napjainkban.

A fészekről való ugrasztás - mivel a szaporodási időszakot megelőző időszakban, vagy a fészkelés során alkalmazható - csak hatósági engedéllyel folytatható (lásd korábban). A még ki nem lombosodott fán messziről megfigyelt és bizonyítottan dolmányos varjú által lakott fészket két oldalról mintegy 15-20 m-re közelíti meg két vadász, lezárva a menekülés irányait. Harmadik társuk megkopogtatja a fészektartó fa törzsét, s a kiugró dolmányos varjat a két vadász közül valamelyik meglőheti. Előrehaladott kotlottság esetén a kotló madár nem ugrik le a fészekröl. Régen ilyenkor azt javasolta a szakirodalom, hogy 8-as söréttel alulról lője ki a vadász a kotló madarat és a tojásokat is. Ma úgy gondoljuk, hogy a hatékony riasztással, és a tojások elszedésével humánusabb megoldást is javasolhatunk. A legjobb megoldás azonban az, ha a később felsorolásra kerülő módszerekkel minél előbb, már a tél végén élünk.

A dolmányos varjút (és a szarkát) döggel is lépre csalhatjuk. A kellő helyen elhelyezett dög messziről vonzza e két fajt, s a lesben ülő vadász kisgolyóssal egyenként kilőheti a dögre szállt madarakat. A meglőtt példányok jelenléte nem hat taszítóan a fajtársakra. Ugyanilyen hatékony lehet az éjszakázó helyek ismeretében a beszállófáknál történő esti és hajnali vadászat is.

Külön kell szólni a müuhuval történő vadászatról. A módszer a ma már fokozottan védett uhu (Bubo bubo) tiltott használatát hivatott kiváltani. A módszer azon a mélységes ellenszenven alapszik, amivel a varjúfélék - és a nappali ragadozó madarak is - viseltetnek az 
éjszakai szárnyas ragadozókkal szemben. Minél nagyobb a madár, annál nagyobb a gyülölet, következésképpen a legnagyobb testủ baglyunk jelenléte váltja ki a szarkánál a legnagyobb indulatokat. A müuhuval való vadászat előkészítését a helymegválasztással kell kezdeni, azaz maghatározni a kialakítandó leskunyhó helyét. Ennek vagy valamilyen magaslaton, de mindenképpen jól látható helyen kell lennie azért, hogy messziröl belátható legyen. A leskunyhó biztosítja a megfelelő takarást, ugyanakkor a vadász védelmét az időjárás ellen. A vadászat másik fontos kelléke a müuhu (praktikusan mủanyag uhu), ami egy szárnyait, sőt fejét is mozgatni képes mechanikus szerkezet, amelyet zsinórok segítségével a kunyhóból lehet mozgatni. Tudni kell, hogy a támadás intenzitása szoros összefüggést mutat az „uhu” aktivitásával, azaz minél jobban rázza szárnyait, annál inkább vonzza ellenségeit. A szük helyre való tekintettel különösen figyelni kell a szabályos fegyverkezelésre (FARAGÓ, 2006).

7. táblázat: A dolmányos varjú (Corvus cornix) teríték dinamikája a LAJTA Projectben (1992-2015) Table 7: Dynamics of Hooded Crow bags in the LAJTA Project (1992-2015)

\begin{tabular}{ccccccccccccccc}
\hline $\mathbf{E ́ v}$ & Jan. & Febr. & Márc. & Ápr. & Máj. & Jún. & Júl. & Aug. & Szept. & Okt. & Nov. & Dec. & Összes \\
Year & Jan. & Febr. & March & Apr. & May & June & July & Aug. & Sept. & Oct. & Nov. & Dec. & Total \\
\hline $\mathbf{1 9 9 2}$ & 0 & 0 & 0 & 1 & 0 & 0 & 1 & 0 & 0 & 0 & 5 & 0 & $\mathbf{7}$ \\
$\mathbf{1 9 9 3}$ & 0 & 5 & 0 & 4 & 0 & 5 & 4 & 6 & 2 & 4 & 0 & 0 & $\mathbf{3 0}$ \\
$\mathbf{1 9 9 4}$ & 0 & 0 & 2 & 1 & 2 & 5 & 1 & 0 & 1 & 2 & 0 & 0 & $\mathbf{1 4}$ \\
$\mathbf{1 9 9 5}$ & 0 & 0 & 0 & 0 & 0 & 0 & 0 & 0 & 0 & 0 & 0 & 0 & $\mathbf{0}$ \\
$\mathbf{1 9 9 6}$ & 2 & 1 & 0 & 4 & 6 & 9 & 4 & 12 & 5 & 0 & 6 & 0 & $\mathbf{4 9}$ \\
$\mathbf{1 9 9 7}$ & 0 & 0 & 2 & 3 & 1 & 3 & 2 & 3 & 2 & 1 & 0 & 0 & $\mathbf{1 7}$ \\
$\mathbf{1 9 9 8}$ & 0 & 1 & 1 & 0 & 1 & 4 & 2 & 4 & 2 & 5 & 8 & 8 & $\mathbf{3 6}$ \\
$\mathbf{1 9 9 9}$ & 3 & 3 & 3 & 4 & 3 & 3 & 4 & 3 & 3 & 5 & 3 & 0 & $\mathbf{3 7}$ \\
$\mathbf{2 0 0 0}$ & 2 & 2 & 5 & 4 & 4 & 4 & 2 & 4 & 1 & 0 & 0 & 1 & $\mathbf{2 9}$ \\
$\mathbf{2 0 0 1}$ & 1 & 0 & 0 & 1 & 0 & 0 & 2 & 1 & 0 & 2 & 1 & 0 & $\mathbf{8}$ \\
$\mathbf{2 0 0 2}$ & 1 & 1 & 1 & 6 & 6 & 7 & 9 & 5 & 0 & 5 & 3 & 10 & $\mathbf{5 4}$ \\
$\mathbf{2 0 0 3}$ & 0 & 4 & 5 & 4 & 7 & 0 & 4 & 0 & 0 & 1 & 6 & 0 & $\mathbf{3 1}$ \\
$\mathbf{2 0 0 4}$ & 2 & 0 & 0 & 0 & 0 & 0 & 6 & 9 & 5 & 3 & 1 & 4 & $\mathbf{3 0}$ \\
$\mathbf{2 0 0 5}$ & 0 & 0 & 0 & 5 & 6 & 4 & 11 & 6 & 1 & 2 & 2 & 0 & $\mathbf{3 7}$ \\
$\mathbf{2 0 0 6}$ & 0 & 0 & 0 & 0 & 0 & 0 & 9 & 2 & 7 & 0 & 2 & 0 & $\mathbf{2 0}$ \\
$\mathbf{2 0 0 7}$ & 4 & 7 & 0 & 0 & 0 & 0 & 13 & 7 & 3 & 2 & 3 & 5 & $\mathbf{4 4}$ \\
$\mathbf{2 0 0 8}$ & 0 & 3 & 0 & 7 & 6 & 3 & 2 & 9 & 5 & 6 & 2 & 2 & $\mathbf{4 5}$ \\
$\mathbf{2 0 0 9}$ & 3 & 4 & 6 & 7 & 12 & 5 & 13 & 11 & 5 & 6 & 3 & 4 & $\mathbf{7 9}$ \\
$\mathbf{2 0 1 0}$ & 4 & 0 & 2 & 2 & 4 & 5 & 12 & 9 & 3 & 4 & 1 & 2 & $\mathbf{4 8}$ \\
$\mathbf{2 0 1 1}$ & 4 & 4 & 2 & 0 & 0 & 6 & 2 & 7 & 10 & 8 & 9 & 7 & $\mathbf{5 9}$ \\
$\mathbf{2 0 1 2}$ & 7 & 5 & 0 & 4 & 8 & 7 & 5 & 16 & 14 & 7 & 6 & 4 & $\mathbf{8 3}$ \\
$\mathbf{2 0 1 3}$ & 6 & 5 & 6 & 6 & 16 & 5 & 4 & 4 & 5 & 3 & 6 & 6 & $\mathbf{7 2}$ \\
$\mathbf{2 0 1 4}$ & 8 & 9 & 0 & 16 & 32 & 20 & 6 & 7 & 4 & 5 & 5 & 7 & $\mathbf{1 1 9}$ \\
$\mathbf{2 0 1 5}$ & 0 & 0 & 0 & 23 & 26 & 4 & 20 & 35 & 49 & 2 & 3 & 2 & $\mathbf{1 6 4}$ \\
\hline Átlag - Mean & $\mathbf{1 , 5}$ & $\mathbf{2 , 0}$ & $\mathbf{1 , 3}$ & $\mathbf{4 , 2}$ & $\mathbf{5 , 3}$ & $\mathbf{4 , 0}$ & $\mathbf{5 , 9}$ & $\mathbf{6 , 4}$ & $\mathbf{4 , 9}$ & $\mathbf{2 , 9}$ & $\mathbf{2 , 9}$ & $\mathbf{2 , 4}$ & $\mathbf{3 9 , 9}$ \\
\hline & & & & & & & & & & & &
\end{tabular}

Fenti módszerek mellett a hivatásos vadászok rendszeres területellenőrzéseik során bármikor elejthetik a dolmányos varjút. A LAJTA Projectben (3060 ha) csaknem negyed század alatt elejtett dolmányos varjak havi átlagos dinamikája szerint (7. táblázat; 2. ábra) a fészkelési és fiókanevelési időszakban (április-szeptember) lötték a legtöbb példányt. A nyári 
megnövekedett teríték a kirepült és kóborló (beleértendök a szomszédos területekröl betelepülök is) példányok megnövekedett számának a folyománya. Ilyenkor lehet hatékony, jövőt alapozó állományszabályozást végezni, ugyanis a fiatal madarak még tapasztalatlanok és könnyebben becserkelhetők.

Fészekfoglalástól az élve fogó csapdák használhatók hatékonyan. Tanácsos megvárni a fészek kitatarozását, vagy új fészek megépítését, hogy a dolmányos varjú kifogása után lakatlanná vált fészek otthona lehessen védett fajoknak (kékvércse, kerecsensólyom, vörös vércse, erdei fülesbagoly stb.).

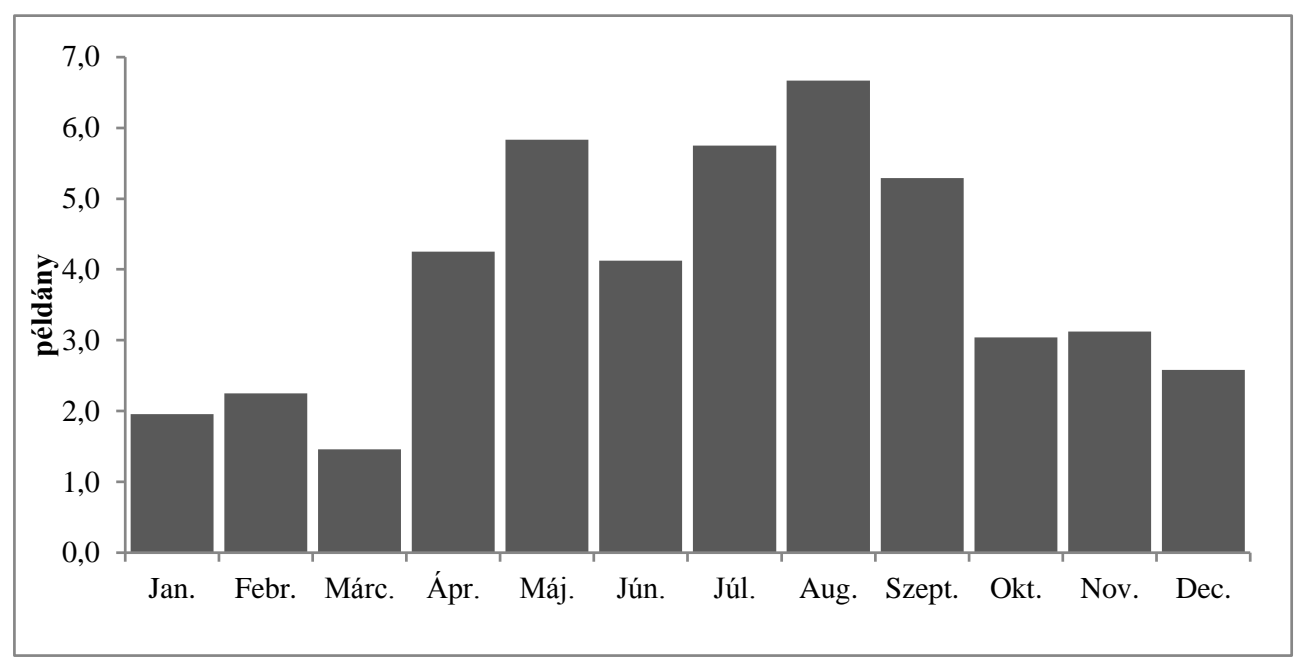

2. ábra: A dolmányos varjú teríték éven belüli megoszlása a LAJTA Projectben

Figure 2: Monthly distribution of Hooded Crow bags in the LAJTA Project

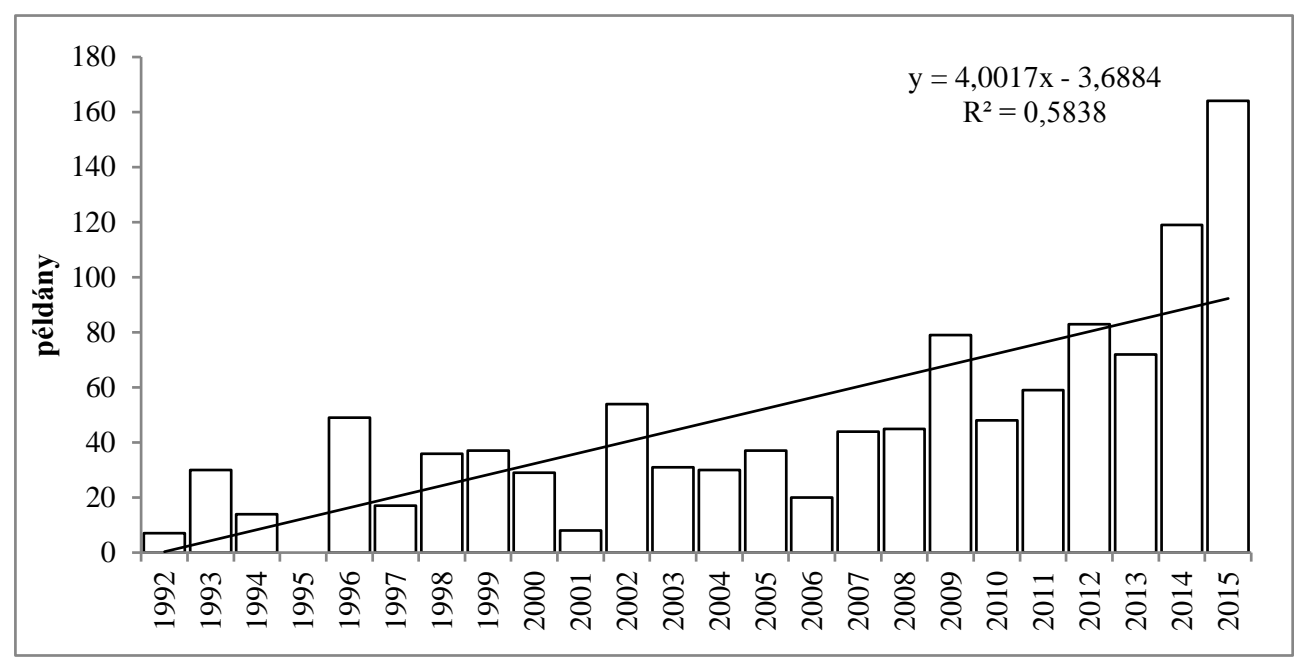

3. ábra: A dolmányos varjú teríték negyedszázados dinamikája a LAJTA Projectben Figure 3: Hooded Crow bag dynamics in the LAJTA Project during the last quarter of century

A tartamos dolmányos varjú állományszabályozás egy vadászterületen azonban ökológiai vákuumot okoz, azaz a szomszédos területekről egyre több példány települ be (3. ábra), ami a regionális szabályozás összehangolását kívánja, sőt kényszerítik ki. 


\section{CSELEKVÉSI TERV}

\subsection{CÉLKITÜZÉS}

A magyar vadgazdálkodás - benne az apróvad-gazdálkodás - célja az apróvad populációk egyedszámának és a fajok elterjedési területének növekedését. Ennek a célnak a megvalósításához az élőhelyek védelmén, fejlesztésén és a dúvadfajok állományszabályozásán keresztül vezet az út. A szárnyas dúvadfajok, azaz a varjúfélék szabályozása a fészkelő vadászható és természetvédelem alatt álló madárfajok támogatását szolgálja. Közülük kiemelt szerepe van a dolmányos varjú populációk kezelésének, szabályozásának.

A dolmányos varjú korábban egész évben vadászható faj volt Magyarországon, amit az EU madárvédelmi irányelv - fészkelő populáció védelme - alapján július 1. - február 28(29). közti időszakra kellett módosítani. E változás következményei - alternatív rendelkezések híján - beláthatatlanok lennének mind a vadgazdálkodás, mind a természetvédelem számára - a faj madárfészekben okozott, fent is említett kártétele miatt. Ennek áthidalására a vadászati rendelet, apróvadas vadászterületeken, az apróvad szaporodási időszakában, a vadászati hatóság külön engedélyéhez kötve lehetővé teszi gyérítését.

Rövidtávú cél, a jelenlegi dolmányos varjú populációk csökkentése a hazai elterjedési terület egészén, de különösen az alföldi apróvadas vadászterületeken. Közép- és hosszútávon, olyan dolmányos varjú állomány-kezelési programot kell megvalósítani, amely alacsony egyedszámú, de önfenntartó dolmányos varjú állománnyal biztosítja a szárnyasvadgazdálkodás és a természetvédelem eredményességét, a faj megőrzése mellett.

Vadvédelmi kötelezettségünknek megfelelően prioritásként kell kezelni a dolmányos varjú állományok szabályozását mind apróvad-védelmi, mind természetvédelmi megfontolásból.

\subsection{FELADATOK}

\subsection{1. Állományszabályozás szükségessége és jogi keretei}

A célkitüzésekben megfogalmazott rövid-, közép- és hosszú távú célok a fenntartható predátor szabályozást erősítik. Rövidtávú cél, a jelenlegi dolmányos varjú populációk csökkentése a hazai elterjedési terület egészén, de különösen az alföldi apróvadas vadászterületeken. Közép- és hosszútávon, olyan dolmányos varjú állomány-kezelési programot kell megvalósítani, amely alacsony egyedszámú, de önfenntartó dolmányos varjú állománnyal biztosítja a szárnyasvadgazdálkodás és a természetvédelem eredményességét, a faj megörzése mellett.

Magyarország EU tagságából adódóan a dolmányos varjú és összességében a vadászható varjúfélék vadászatára az Európai Parlament és a Tanács a vadon élő madarak vélelméről szóló 2009/147/EK irányelve (a továbbiakban Madárvédelmi Irányelv) rendelkezései az irányadók, amelyek beépültek a vad védelméröl, a vadgazdálkodásról, valamint a vadászatról szóló 1996. évi LV. törvénybe (a továbbiakban Vtv.) és az annak végrehajtásáról szóló 79/2004 (V.4.) FVM rendeletbe (a továbbiakban Vhr.). A hivatkozott jogszabályok egyértelműen rendelkeznek a vadászható fajok köréről, a vadászati módokról és idényekről.

Magyarország, a Madárvédelmi Irányelv 7. cikk (3) bekezdése, valamint a II. melléklet B része alapján azon tagállamok közé tartozik ahol a dolmányos varjú, a szarka és a szajkó, valamint a vetési varjú vadászata engedélyezhető. A Vhr. 1. § (1) bekezdés bb) 9-11. pontjai 
alapján az első három faj vadászható, egyúttal a (2) bekezdés alapján közösségi jelentőségü vadászható fajnak minősül, míg a védett és a fokozottan védett növény- és állatfajokról, a fokozottan védett barlangok köréről, valamint az Európai Közösségben természetvédelmi szempontból jelentős növény- és állatfajok közzétételéröl szóló 13/2001. (V. 9.) KöM rendelet 2. számú mellékletében felsorolt vetési varjú védett.

A Madárvédelmi Irányelv 7. cikk (4) bekezdése alapján a hatályos nemzeti elöírások szerint történő vadászat meg kell, hogy feleljen az ésszerü hasznosítás és az ökológiailag kiegyensúlyozott állományszabályozás elveinek, továbbá a vadászható fajok esetében is biztosítandó, hogy azokat ne lehessen sem a fészekrakás, sem a fiókanevelés, vagy a szaporodás különböző szakaszaiban vadászni. Elözőeknek megfelelöen a Vtv. 28. § (4) bekezdésének a) pontja általánosan tiltja a madárfajok fészkének és fészkelésének zavarását, megrongálását, vagy elpusztítását, míg a 38.§ (4) bekezdése alapján a vadászható madárfajok egyedeire, a fészekrakás és fiókanevelés időszakában, illetve a szaporodási időszakban vonuló fajok esetében a fiókanevelési területükre történő visszatérésük során történő vadászatot. A Vhr. 5. számú mellékletében megállapított vadászati idénye a vadászható varjúféléknek a hivatkozott rendelkezésekkel összhangban július 1-én kezdődik és február utolsó napjáig tart.

Figyelemmel kell azonban arra is lenni, hogy a Madárvédelmi irányelv 1. cikkében meghatározottak szerint az a tagállamok Szerződésben érintett európai területén természetesen előforduló összes vadon élő madárfaj védelmére vonatkozik. Továbbá arra is, hogy a 2. cikk alapján szükséges az 1. cikkben meghatározott fajok állományait (így az apróvadfajokét is) megfelelö szinten fenntartani, vagy olyan szintre hozni, amely megfelel különösen az ökológiai, tudományos és kulturális követelményeknek, figyelembe vége a gazdasági és rekreációs követelményeket is, ezért szükségessé válhat a varjúfélék gyérítése a vadászati idényen kívüli időszakban is.

A dolmányos varjú, a szarka és a szajkó idényen kívüli vadászatát a Vtv. 38. § (3) bekezdésének b) pontjára alapozottan a vadászati hatóság - közösségi jelentőségü vadászható vadfaj vonatkozásában a 38/A. § (1)-(3) bekezdésében foglaltak szerint engedélyezheti, egészen pontosan a Vhr. 27. § (7) bekezdésében foglaltaknak megfelelően, apróvadas vadászterületeken, az apróvad szaporodási időszakában. Ezen rendelkezés, összhangban áll a Madárvédelmi irányelv 9. cikk (1) bekezdése alatt meghatározott feltétellel, amely kimondja, „ha nincs más megfelelő megoldás” a tagállamok ,eltérhetnek az 5-8. cikk rendelkezéseitől az a), b) és c) pontok alatt felsorolt okok miatt, amelyeket a Vtv. 38/A. § (1) bekezdésének a) f) pontjai tartalmaznak. Tételesen felsorolva ezek a következök:

a) közegészségügyi, illetve közbiztonsági okból,

b) a légi közlekedés biztonsága érdekében,

c) a növényi kultúrák, a termés, az állatállomány, az erdők, a halállományok, a vizek súlyos károsodásának megelözése érdekében,

d) kutatás és oktatás, állományfeljavítás, visszatelepítés és az ezekhez szükséges tenyésztés céljából,

e) egyes vadászható madárfajok - az érintett állomány nagyságához mérten kisszámú szelektív befogásának, tartásának, illetve hasznosításának érdekében, vagy

f) a vadon élő állatok és növények, valamint a természetes élöhelyek védelme érdekében. 
A vadgazdálkodás és a természetvédelem számára legfontosabb a felsorolt indokok között a vadon élő növény- és állatvilág védelme érdekében engedélyezett eltérési lehetőség (lásd Vhr. 27. § (7) bekezdése), ami jelentős mértékben járulhat hozzá az apróvad, valamint a földön fészkelő védett madárfajok (pl. túzok, szikipacsirta, haris, bíbic) megőrzési erőfeszítéseinek sikeréhez. Az idényen kívüli vadászat engedélyezéséről szóló hatósági döntésnek a Vtv. 38/A $\S(2)$ bekezdés a) - e) pontjai szerint meg kell határoznia

a) a vadfajt és az egyedek számát,

b) a befogás vagy elejtés módját, eszközeit,

c) azt a területet, amelyen a tevékenység gyakorolható,

d) a tevékenység időtartamát, és

e) a tevékenység vadászati hatóság általi ellenőrzésének módját.

Ezeken túlmenően, az engedélyes a tevékenység végrehajtásáról a vadászati hatóságnak, míg utóbbi a földmüvelésügyi miniszternek tartozik beszámolási kötelezettséggel, aki a természetvédelemért felelős miniszter útján - közösségi jelentőségü vadászható vadfaj esetében kétévente (derogációs) jelentést küld az Európai bizottság részére.

A Vtv. 30. § (1) bekezdése rendelkezik arról, hogy a vadat elejteni, elfogni, kizárólag a törvényben meghatározott módon szabad, egyúttal tiltja a méreg alkalmazását. Utóbbi tiltás alól ugyanezen jogszabályhely (2) bekezdése ad felmentést, azzal a kitétellel, hogy közösségi jelentőségü vadászható vadfaj vonatkozásában a 38/A. § (1)-(3) bekezdésében foglaltak szerint - a mérgező hatású anyagok használatára vonatkozó külön jogszabályok figyelembevételével engedélyezhető szelektív méreg alkalmazása. A Vhr. 60. § (2) bekezdése szerint a szelektív hatású vegyszer abban az esetben használható többek között dolmányos varjú, szarka és szajkó elpusztítására, amennyiben az védett állatot nem veszélyeztet. Mivel mind a holló, mind pedig a vetési varjú védett, kézenfekvőbb a varjúfélék gyérítését csapdázásra alapozottan végezni.

A Vtv. 67 (3) kezdése a vad elfogását az e célra szolgáló hálóval, befogó karámmal, altató-, bénítólövedékes fegyverrel, valamint a vonatkozó közösségi rendeletben nem tiltott, illetve megengedett csapdázási módszerrel teszi lehetővé. A Madárvédelmi Irányelv 8. cikke és IV. melléklete alatt meghatározott tiltott befogási eszközöket és módszereket a Vtv. 68. § (1) bekezdésének f) és g) pontjai, valamint a Vtv. 71. § (2) bekezdésének f), g), j) l) és m) pontjai tartalmazzák. Előbbi jogszabályhelyek tiltják a hurok, a horog, a madárlép, valamint a müködése, vagy felhasználása körülményei folytán nem szelektív háló alkalmazását. Az utóbbi rendelkezések szerint pedig a vadászat rendje megsértésének minősül a vad megtévesztésére szolgáló elektronikus akusztikai eszköz, vagy mesterséges anyag, valamint a vak és megcsonkított élö csali-állat, a tükör és más vakító eszköz, a mérgezett vagy altató csalétkek, továbbá a madarak tömeges, vagy nem szelektív befogását, vagy elpusztítását eredményező, illetve a fajok helyi eltünését eredményező csapdázási eszköz, illetve eljárás és módszer.

Tekintettel az élö csali-állat gyakori alkalmazására meg kell említeni, hogy a Madárvédelmi Irányelv 6. cikk (1) bekezdésére alapozottan, a Vhr. 45. § (2) bekezdése nem engedi többek között a dolmányos varjú, a szarka és a szajkó élő vagy elpusztult, illetve elejtett egyedeinek és származékainak vagy könnyen felismerhető részeinek eladását, eladásra történő szállítását, eladásra történő tartását, valamint eladásra történő felkínálását sem. 


\subsubsection{Az állományszabályozás információszükséglete}

Az apróvadas vadászterületeken a predátorok (köztük a dúvadfajok) populációinak ismerete nélkülözhetetlen. A szőrmés és szárnyas ragadozók állományainak szabályozása, illetve a vadfajok és a velük együtt élő védett fajok védelme szükségessé teszi, hogy a vadgazda mindezekről információkat szerezzen. A vadfajok szaporodási időszakát megelőzően, illetve részben az alatt, a predátor fajok állományait úgy ismerhetjük meg és úgy szabályozhatjuk, ha ismerjük otthonaik helyét. A varjú-félék és a ragadozó madarak fészkei, illetve a róka és a borz kotorékai könnyen megtalálhatók és ellenőrizhetők.

A ragadozó madarak és varjúfélék - közöttük a dolmányos varjú - fészekfelmérésével az adott évi fészkelő állomány nagysága és diszperziója viszonylag könnyen meghatározható. Segítségünkre van ebben az, hogy az említett fajok vagy korábbi fészkeket tataroznak ki költésükhöz, vagy még a fák kilombosodása elött építik fészkeiket. A fészekkataszter, melyet évről-évre vezethet a hivatásos vadász (vagy vadászok), segít a könnyebb megtalálásban, illetőleg az új fészkek helyének rögzítésében. (A varjúfélék fészkeinek környékén elhelyezett LARSEN- vagy TROLLE-LJUNGBY L84 csapda alkalmazásával a dúvadgyérítést is hatékonnyá lehet tenni. Példaként (6. térkép) a LAJTA Project fészekfelméréseit mutatjuk be (FARAGÓ et al., 2012 és aktualizálva).

A vadászterület (vizsgálati terület) térképén bejelölendő minden fészek helye, $s$ azok mindegyike sorszámot, illetve önálló kartont kap (természetesen napjainkban már a számítógépes nyilvántartás is szóba jön.). A kartonokra évről-évre fel kell jegyezni az a fészekben található fajokat, az esetleges szaporulatot, a gyérítés módját és eredményességét. Ha új fészek készül az idők során, akkor azt új sorszámmal kell szerepeltetni. A kartonokra a mennyiségi adatokon túl szaporodásbiológiai és fenológiai adatok is rögzíthetők. A lakott fészkek számából és az abban észlelt egyedszámból az aktuális állománynagyság, a szaporodási rátákból pedig a populáció változásának gyérítés nélküli dinamikája is előremetszhető, s a szükséges mérvü beavatkozás is megtervezhető (FARAGÓ \& NÁHLIK, 1997).

A dolmányos varjú (és más dúvad fajok) állománynagyságának ismerete legalább olyan fontos az apróvaddal foglalkozó vadgazda számára, mint magának az ún. haszon vadnak az ismerete, hiszen anélkül és a velük való gazdálkodás híján munkájának hatékonysága alacsony fokú lesz.

Jelentőség: Magas (8-10)

Hatékonyság: Magas (9)

Ütemezés: folyamatos, de különösen s fészkelési időszak előtt és alatt

Felelős: Földmüvelésügyi Minisztérium, megyei Kormányhivatalok, OMVV, OMVK, Együttmüködők: Vadgazdálkodók, természetvédelmi hatóságok, Nemzeti Parkok 

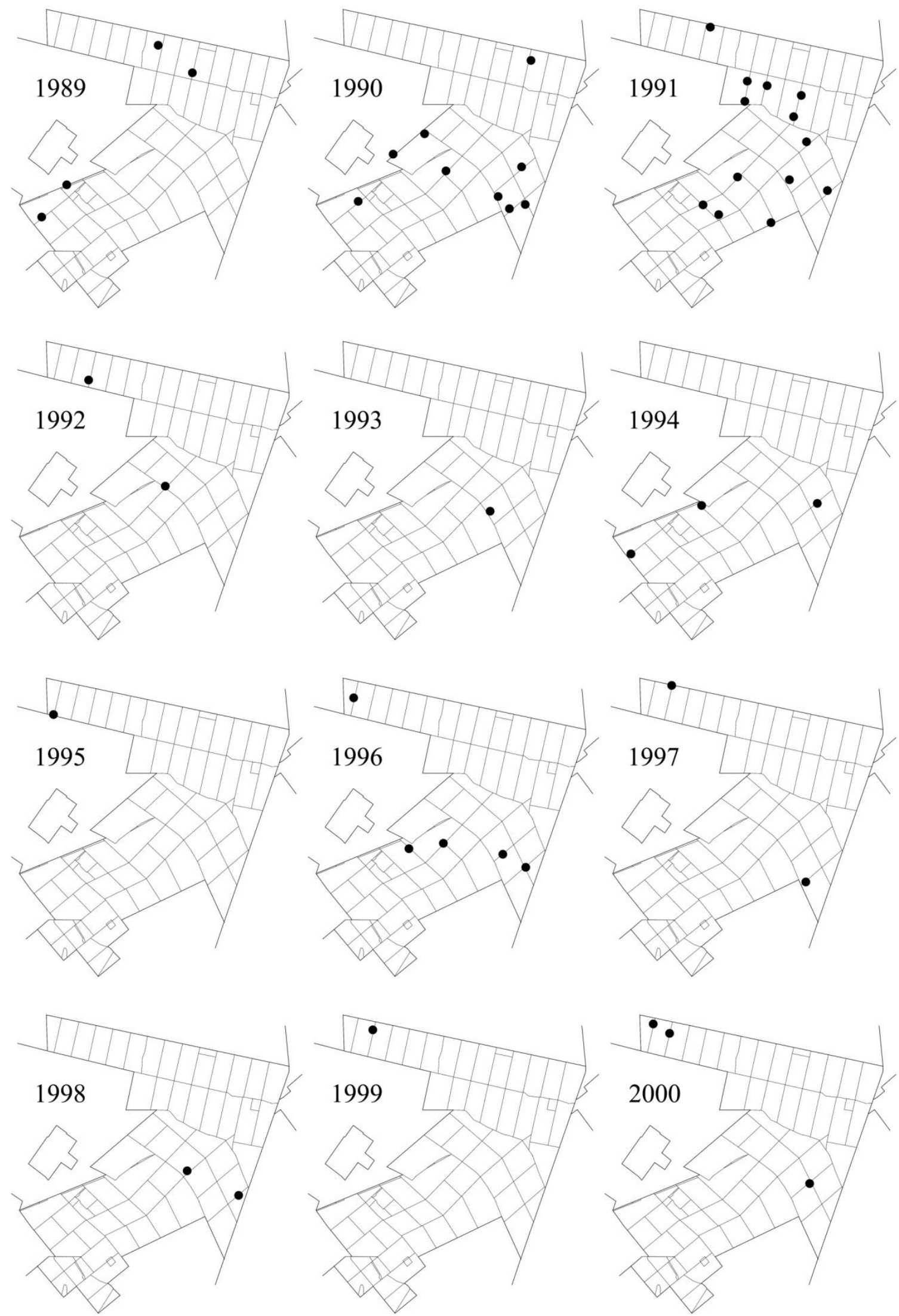

6. térkép: A dolmányos varjú fészkek elhelyezkedése a LAJTA Projectben Map 6: Distribution of Hooded Crow nests in the LAJTA Project 

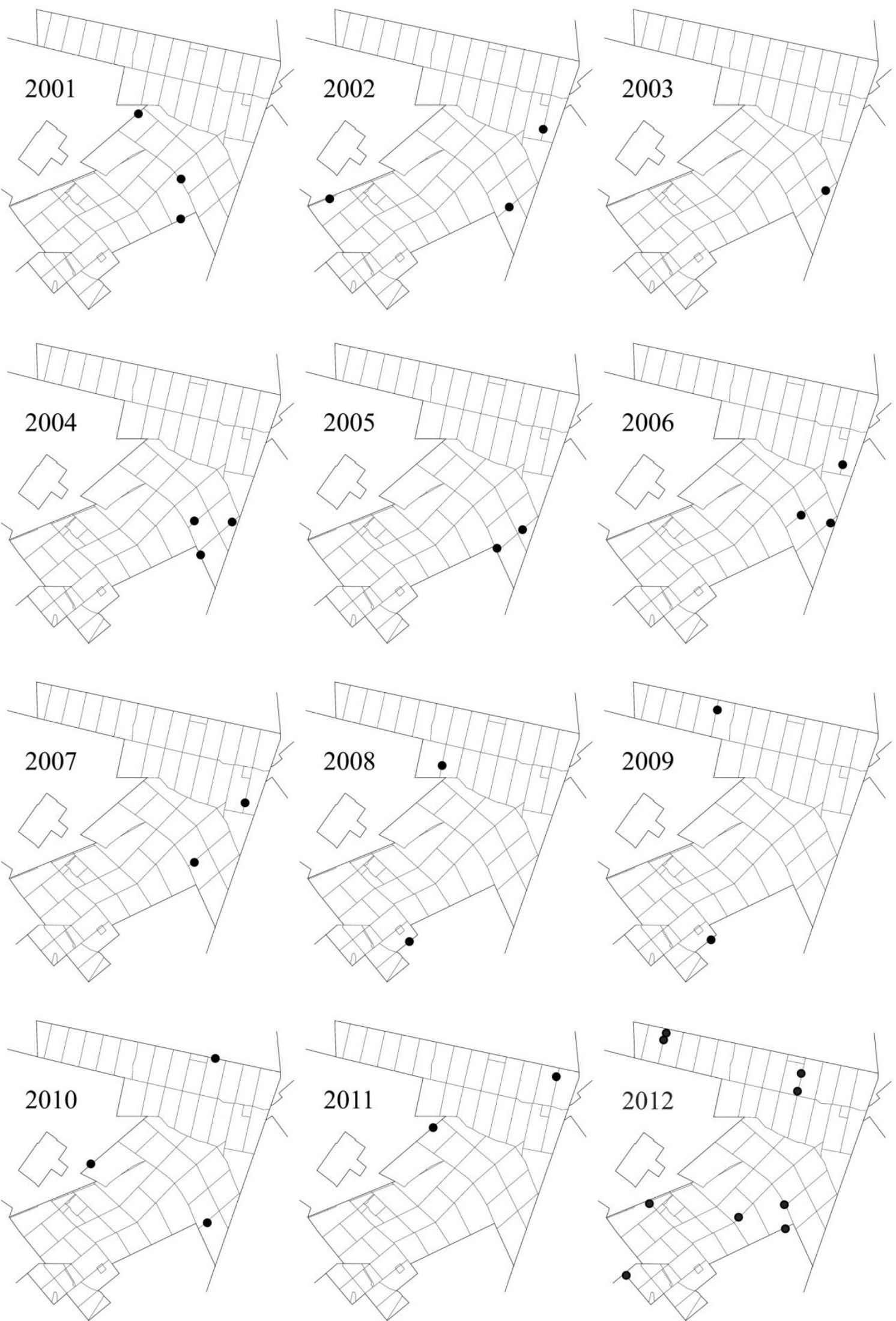

6. térkép (folyt.): A dolmányos varjú fészkek elhelyezkedése a LAJTA Projectben Map 6 cont.: Distribution of Hooded Crow nests in the LAJTA Project 


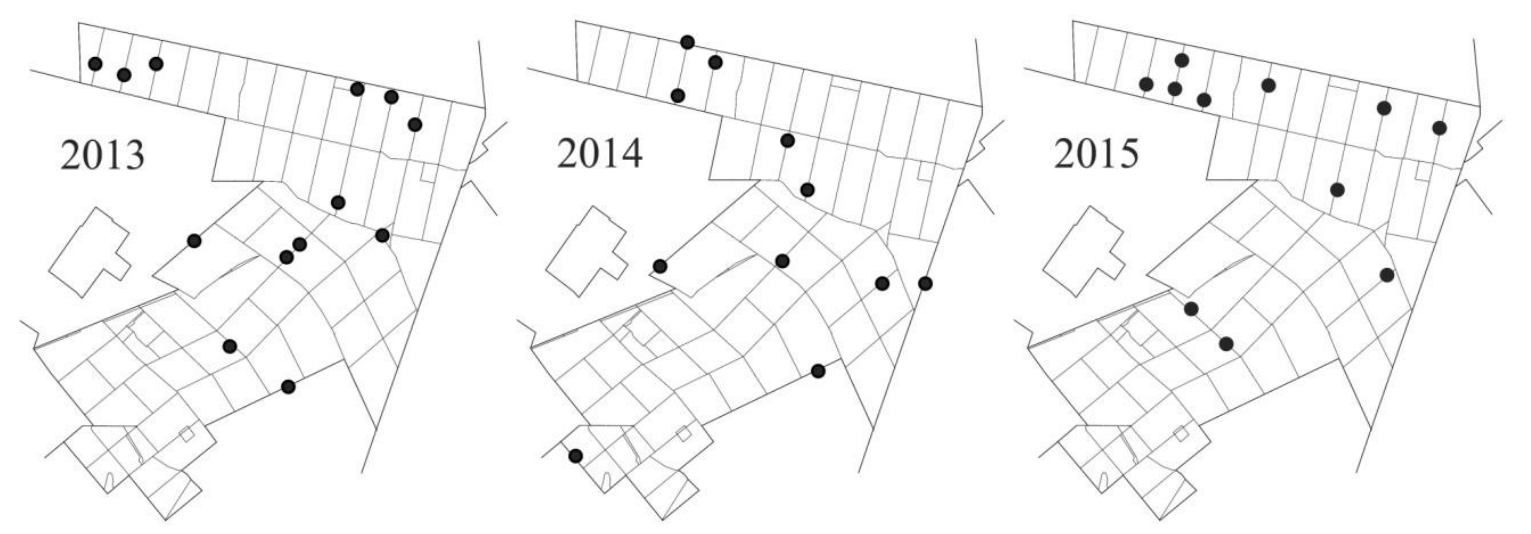

6. térkép (folyt.): A dolmányos varjú fészkek elhelyezkedése a LAJTA Projectben

Map 6 cont.: Distribution of Hooded Crow nests in the LAJTA Project

\subsubsection{Az állományszabályozás ideje}

A dolmányos varjú állományszabályozását a Vt. végrehajtási rendelete határozza meg. Július 1. - február 28(29). közötti időszakban gyéríthető (lőhető, csapdázható). A fészkelési időszak (mind a dolmányos varjú, mind a zsákmányolt madárfajok esetében) kizárása beláthatatlan következményekkel járna mind a vadgazdálkodás, mind a természetvédelem számára - a faj madárfészekben okozott kártétele miatt -, de a vadászati rendelet, apróvadas vadászterületeken, az apróvad szaporodási időszakában, a vadászati hatóság külön engedélyéhez kötve lehetővé teszi gyérítését.

A jó gyakorlat (2. ábra) azt mutatja, hogy egész évben kell a szabályozást folytatni, de különösen az április-augusztus időszak a hatékony.

\subsubsection{Az állományszabályozás eszköztára}

\subsubsection{Fegyveres szabályozás}

A fegyveres szabályozás folytatható egész évben, de egyes időszakokban az eltérő módszerek hatékonysága eltérö, illetve kizárólagos lehet.

A fészekről történő ugrasztás értelemszerüen a fészkelési időszakra összpontosít. Dögön történő vadászat mindenkor, de különösen a táplálékban szegényebb időszakokban hatékony. Ugyanez mondható el a müuhuval való vadászatról is. Utóbbi inkább a kóborlás időszakában lehet eredményes. Rendkívül fontos a hivatásos (és sport) vadászok esetében a lőjellel való elszámolás, annak nyilvántartása. A dolmányos varjú szabályozás lőjelek utáni premizálása (lőszer, vagy pénz) a hajlandóságot erősíti, és a hatékonyságot növeli.

Jelentőség: Magas (8-10)

Hatékonyság: Magas (8-10)

Ütemezés: Egész évben

Felelős: megyei vadászati hatóságok

Együttműködők: OMVV területi szervezetei, vadgazdálkodók, nemzeti parkok 


\subsubsection{2. Élve fogó csapdázás}

A varjúfélék, elsősorban a szarka, a dolmányos varjú (és Nyugat-Európában a kormos varjú) csapdázása általánosan elterjedt vadgazdálkodási és természetvédelmi gyakorlat, amelyet Európa mindegyik vadászati kultúrkörébe tartozó területen alkalmaznak. Eredményességét több szerző pl. StUBBE (1977) TAPPER et al. (1991), TAPPER et al. (1996), FARAGÓ (1997), ADVISORY SERVICE OF GAME CONSERVANCY LTD (2005), WESTERKAMP (2006), SAULNIER (2008), HAJAS (2009) és KARLSSON (2009) is említi.

A 4. ábrán láthatók azok az eszközök, amelyekkel szarka (valamint a dolmányos varjú) eredményesen csapdázható.

A kandli elsősorban a csalimadárfogás, míg a 4.2 képen bemutatott LARSEN csapda (HAJAS, 2007, 2011) és a svéd Trolle-LJUngbY L84 csapda (HAJAS, 2012) a tavasszal territóriumot foglaló és párba állt szarkák, illetve varjak gyérítésének eszközei.

A létrás csapda (STUBBE, 1977; BUB, 1995) optimális használati időszaka nyár közepétől tél végéig tart, azonban elsősorban a dolmányos varjú csapdázásának elengedhetetlen berendezése.

A kandli kivételével mind a LARSEN- és a TROLlE-LJUnGBy L84, mind pedig a létrás csapdához élő csalimadár használatára van szükség.
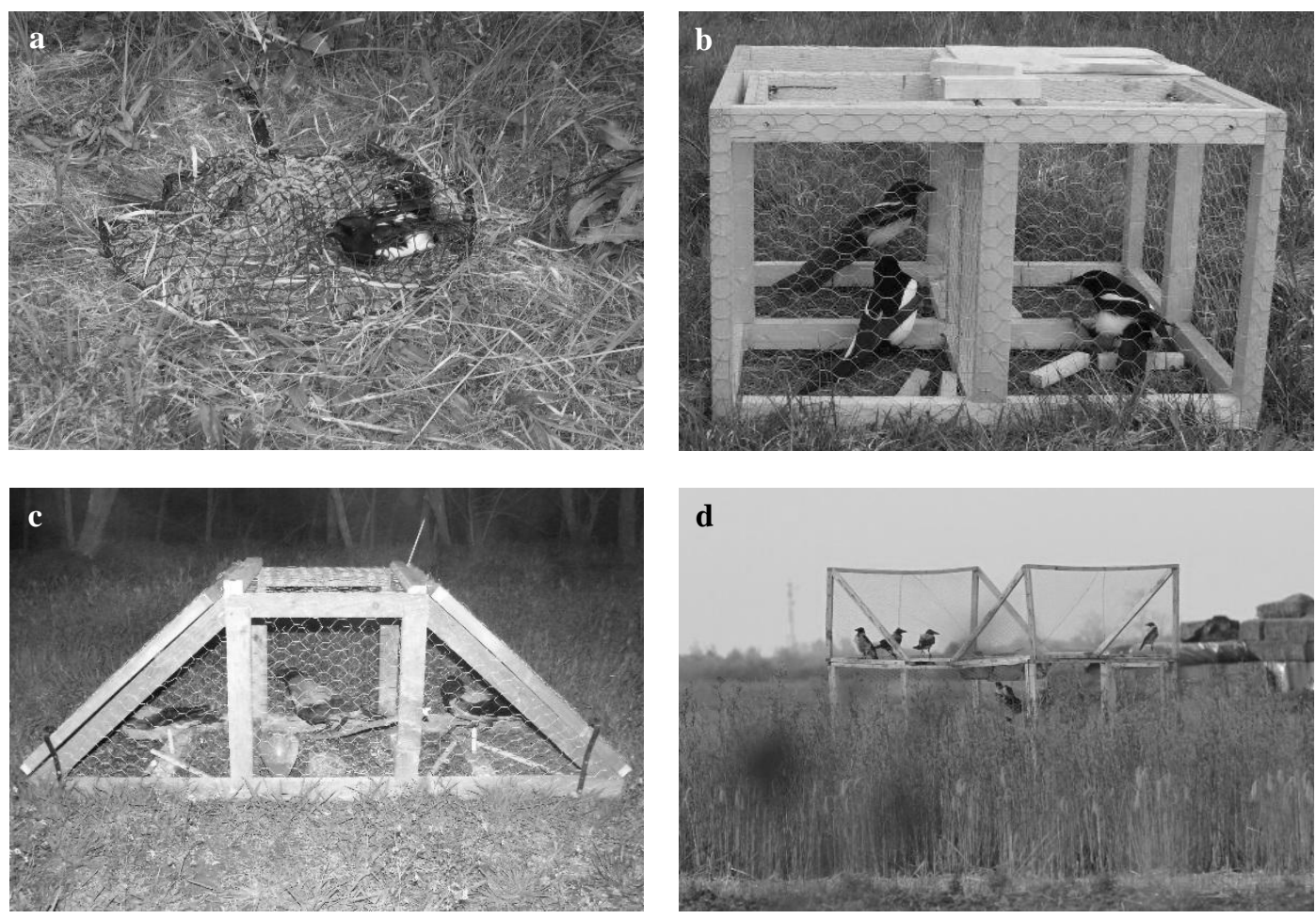

4. ábra: Varjúcsapdák: a. Kandli (Fotó: NAGY B.), b. LARSEN csapda (Fotó: HAJAS P.P.), c. TROLLE-LJUNGBY L84 svéd csapda (Fotó: TöröK P.), d. Létrás csapda (Fotó: HAJAS P.P.)

Figure 4: Crow traps: a. Bow net (Photo: B. NAGY), b. Larsen trap (Photo: P.P. HAJAS), c. TROLLE-LJUNGBY L84 swedish trap (Photo: P. TÖRÖK), d. Ladder trap (Photo: P.P. HAJAS)

Szabadterületen csalimadarat legkönnyebben kandlival lehet befogni, amelyet a szarkák és a dolmányos varjak kedvelt beülőfái közelében célszerü elhelyezni - kellő gondosságú álcázást követően. A csali lehet mesterséges fészekben elhelyezett tojás (lehetőleg galamb, vagy fácán), dög, de akár kenyér is. A kialakított fészekböl egy tojást lehetőleg össze kell törni, hogy az már prédáltnak tünjön, ezáltal is növelve a megfogni kívánt szarka, vagy dolmányos varjú érdeklődését. 
A csalimadarak számára kellő takarást, ülő rudat, valamint tiszta vizet és állati fehérjében dús takarmányt kell biztosítani. Az állatjóléti szempontokon túlmenően, a hatékonyság szempontjából is fontos, hogy a csalimadarak kondíciója jó legyen, ugyanis a leromlott állapotú „,betolakodó” nem jelent kihívást a territóriumát védő pár számára. Esős időszak során a csalimadarakat a számukra kialakított, nagyobb mozgást és szárítkozást lehetővé tévő röpdében kell tárolni, amely szolgálhat a befogott madarak egy részének átteleltetésére is, hogy könnyebben lehessen megkezdeni a rákövetkező év tavaszán induló csapdázási kampányt. Egy röpdében csak egy fajhoz tartozó csalimadarakat szabad tárolni.

A dolmányos varjú leghatékonyabb csapdázási időszaka április 15. és május 31. közötti, amikor fiókákat nevelő felnőtt madarak sokkal érzékenyebben reagálnak a fészek közelében megjelenő idegen fajtársra és a mellette elhelyezett élelemre. Amennyiben a társfészkelő fajok számára fontos a fészkek rendbetétele, a szaporodási időszak elején még nem, csak a költési időszak kezdetével szabad a csapdázást megkezdeni. Általában a tojókat sikerül elsőként megfogni, amelyekkel a csalimadarat kicserélve a párjuk is megfogható.

Az élő csali mellett a fent leírt okokból a fogórekeszekben egy-egy tojást, vagy más táplálékforrást kell elhelyezni. Amint a territoriális pár egyedeit a fészek közelében elhelyezett csapdával sikerült megfogni, azt tovább lehet mozgatni.

Létrás, vagy varsás csapdát szarka befogására a nyár közepétől tél végéig terjedő időszakban legfeljebb nagyvárosok, vagy szemétlerakók környékén érdemes használni, ahol a nagy mennyiségben gyülekező madarak egyidejü befogásával megkönnyíthető a következő tavaszi szezon munkája.

A varjúfélék csapdázására használt eszközöket a tanulás és a csapdához való hozzászokás elkerülése érdekében lehetőleg a madarak aktív időszakán kívül, kora hajnalban, vagy az esti órákban kell telepíteni és ellenőrizni, ez különösen a dolmányos varjú esetében fontos. Kötelező a napi rendszerességgel történő ellenőrzés!

A csapdákkal megfogott nem célfajok egyedeit, eltérő módon rendelkező engedély hiányában a befogás helyén, az észlelést követően haladéktalanul szabadon kell engedni. A megfogott szarkákat és dolmányos varjakat kíméletesen és gyorsan kell elpusztítani.

Jelentőség: Magas (9-10)

Hatékonyság: Magas (9-10)

Ütemezés: évente március 1. és május 31. között

Felelős: FM Erdészeti és Vadgazdálkodási Főosztály, megyei vadászati hatóságok

Együttmüködők: vadgazdálkodók, Országos Magyar Vadászati Védegylet

\subsubsection{Kémiai szabályozás lehetőségei és korlátai}

A varjúfélék szabályozásánál/gyérítésénél meg kell említenünk az F-1 és F-2 néven, korábban Fácánkerten előállított, varjú-félékre szelektív szerrel (hatóanyaga 3-kloro++-4-metilanilinhidroklorid) preparált tojások alkalmazását (KALOTÁs \& NIKODÉMUSZ, 1982). Rendkívül hatékony módszer volt. Alkalmazása során kizárták azokat a területeket, ahol a holló (Corvus corax) fészkelt. Mivel a holló elterjedése - nem utolsó sorban a jelentősen megnövekedett nagyvad állomány vadászata során keletkezett és a vadászterületeken hagyott zsigerek fogyasztása következtében - jelentősen megnőtt, egyre szükebb volt felhasználhatóságának körzete. Emellett hatékonyságának túlzott eredményessége okán, a drámain lecsökkent állományú, ezért 2000-ben védetté váló fészkelő vetési varjú (Corvus frugilegus) elvárt kímélete miatt, a szer használatát előbb fel kellett függeszteni, külön engedélyhez kellett kötni, majd betiltásra került. Más módszer a kémiai szabályozásra nem ismert, így ezt a szabályozási lehetőséget - említett okok miatt - a jövőben nem lehet számításba venni. 
Jelentőség: Magas (8-10) - de tiltott alkalmazás!

Hatékonyság: Magas (8-10) - de tiltott alkalmazás!

\subsubsection{A szabályozás természetvédelmi vonatkozásai}

A dolmányos varjú állomány szabályozásának - mint láttuk - egyik leghatékonyabb eszköze a fészkelő állomány alacsony szinten tartása. Ennek végzése során messzemenően figyelembe kell venni a természetvédelem érdekeit. A dolmányos varjú potenciális „szálláscsinálója” védett, olykor ritka ragadozó madaraknak (pl. kékvércse, kerecsensólyom, vörös vércse, erdei fülesbagoly stb.). Ezért a fészeknél történő tevékenységnél fokozottan kell figyelni annak időbeli lehetőségeire. Csak a fészektatarozás, vagy megrakás után történjen meg a dolmányos varjú pár eltávolítása.

A fészekről való ugrasztás során győződjön meg a vadász, hogy valóban dolmányos varjú lakja a fészket és nem történt meg időközben gazdacsere, azaz védett faj fészekfoglalása, ezáltal megelőzhető a tévedésen alapuló törvénysértés

Jelen körülmények között - tekintettel a holló (Corvus corax) széleskörü elterjedésére, a 3-kloro-4-metilanilin-hidroklorid hatóanyaggal preparált - varjúfélékre szelektív - tojások alkalmazása a jövőben sem engedélyezhető.

Jelentőség: Magas (8-10)

Hatékonyság: Közepes (6)

Ütemezés: folyamatos

Felelős: megyei vadászati és természetvédelmi hatóságok

Együttmüködők: OMVV és területi szervezetei, vadgazdálkodók, OMVK és területi szervezetei, nemzeti parkok

\subsubsection{Tanácsadás vadgazdálkodók számára}

Minden lehetséges módon (különösen a hivatásos vadász továbbképzéseken) meg kell ismertetni a gazdálkodókkal a dolmányos varjú (általában a dúvad fajok) tényleges vadgazdálkodási jelentőségét, predációs súlyát.

Jelentőség: Magas (8-10)

Hatékonyság: Közepes (6)

Ütemezés: Költési és fiókanevelési időszak előtt, évente ismételve

Felelős: megyei vadászati hatóságok

Együttmüködők: vadgazdálkodók, Országos Magyar Vadász Kamara

\subsubsection{Oktatás és továbbképzés}

A dolmányos varjú szabályozására vonatkozó ismeretek oktatása és annak folyamatos aktualizálása fontos az alap-, közép- és felsőfokú vadgazdálkodási (és természetvédelmi) szakemberképzésben. Az oktatást végző intézmények tananyagai, tankönyvei és jegyzetei tartalmazzák a predátor gazdálkodás elméleti és gyakorlati ismeretanyagát. A vadgazdálkodási szakemberek rendszeres továbbképzései során ugyancsak ismertetni kell szabályozás célkitüzéseit, módszereit és eredményeit.

Jelentőség: Magas (8-10)

Hatékonyság: Közepes (6) 
Ütemezés: Folyamatosan

Felelős: OMVV, OMVK országos és megyei területi szervezetei, NyME-EMK Vadgazdálkodási és Gerinces Állattani Intézet

Együttműködő: szakirányú képzést folytató alap-, közép- és felsőfokú oktatási intézmények

\subsubsection{Kutatás és monitoring}

A kutatásnak a faj hazai jobb megismerését szolgáló célt kell szolgálnia. Ezek föbb elemei a következők:

- Populáció diszperziója, szaporodási viszonyai

- Táplálkozása megváltozott körülmények között

- Élőhely-monitoring (fészkelöhely, táplálkozóhely)

- A vadászati nyomás vizsgálata

- Csapdázási eredményesség elemzése

Jelentőség: Magas (8-10)

Hatékonyság: Közepes (6-7)

Ütemezés: Folyamatosan

Felelős: NymE EMK Vadgazdálkodási és Gerinces Állattani Intézet

Együttmüködő: más felsőoktatási intézmények, vadgazdálkodók

\subsubsection{Kommunikáció és nyilvánosság}

\subsubsection{Kommunikáció az érintett hatóságokkal}

A predátor (benne a dolmányos varjú) állományok szabályozásának hatékonysága érdekében a vadgazdálkodóknak jó kapcsolatokat kell kialakítani valamennyi, annak sikerességét elősegítő hatósággal:

- megyei vadászati hatóságok

- FM Erdészeti és Vadgazdálkodási Főosztály

- NÉBIH

- természetvédelemért felelős hatóságok

- Területileg illetékes rendőrkapitányságok és ügyészségek

Jelentőség: Magas (8-10)

Hatékonyság: Jó (8)

Ütemezés: Folyamatosan

Felelős: FM Erdészeti és Vadgazdálkodási Főosztály

Együttmüködők: vadgazdálkodók, Országos Magyar Vadász Kamara, Országos Magyar Vadászati Védegylet

\subsubsection{Kommunikáció a nagyközönséggel}

Kellő rendszerességgel tájékoztatni kell a nagyközönséget a dúvadszabályozás szükségességéről és helyzetéről.

Különösen fontos a nagyközönséggel megismertetni az írott és elektronikus médián keresztül a dúvadszabályozás szerepét, fontosságát és szabályozottságát. A kommunikáció súlyát növeli annak állatvédelmi vonzatai miatt. Kiemelt jelentősége van a helyi sajtón, információs anyagokon, plakátokon keresztüli tájékoztatásnak. 
Jelentőség: Magas (8)

Hatékonyság: Közepes (6)

Ütemezés: Aktualitások figyelembe vételével, évente ismételve

Felelős: Földművelésügyi Minisztérium, megyei Kormányhivatalok, OMVV, OMVK, NyME-EK Vadgazdálkodási és Gerinces Állattani Intézet

\subsubsection{Felülvizsgálat}

A Dolmányos Varjú Kezelési Terv megvalósítását évente áttekinti az Országos Vadgazdálkodási Tanács, és állásfoglalása alapján értékeli az FM Erdészeti és Vadgazdálkodási Főosztálya, amely azután - ha a szükség úgy kívánja - meghozza a szükséges intézkedéseket.

\section{3. ÖSSZEFOGLALÁS}

\section{1. ÁlLOMÁNYSZABÁlYOZÁSI HELYZET}

A 2000-es évek első évtizedében 51 000-84000 párban adták meg a hazai fészkelő szarkapopulációt (MME NOMENCLATOR BIZOTTSÁG, 2008). A korábban ennél feltételezhetően lényegesen magasabb állomány elsősorban a kémiai szerekkel történő szabályozás hatására csökkent le. Napjainkban 20 ezer példányos terítéke az apróvadgazdálkodási célok teljesítéséhez nem elégséges.

\subsection{KEZELÉSI PRIORITÁS}

A dolmányos varjú, mint a szárnyasvadfajok egyik legfontosabb fészekpredátora, a vadgazdálkodási intézkedések tekintetében a magas prioritást érdemel.

\subsection{CÉLOK}

Rövidtávon, a jelenlegi dolmányos varjú populációk csökkentése a hazai elterjedési terület egészén, különösen a Duna-Tisza közén és a Tiszántúlon. Közép- és hosszútávon, olyan dúvadszabályozási programok megvalósítását kell szorgalmazni, amelyek lehetővé teszik a populációk egyedszámának csökkentését és alacsony szinten tartását.

\section{4. ÁTFOGÓ KEZELÉSI POLITIKA}

Prioritás kell, hogy legyen a dúvadszabályozás - lelövéssel és csapdázással.

\subsection{CSELEKVÉSI TERV}

\section{1. Élőhely-gazdálkodás}

C1.1. A dúvad-gazdálkodást kiemelten kell kezelni, és az éves tervekben rögzíteni kell előírásait. A hatósági munka során érvényt kell szerezni betartásuknak.

Nagy jelentőségü, hatékony. Felelős szervezet: megyei vadászati hatóságok,OMVV megyei szervezetei 


\section{Politika és jogalkotás}

C.2.1. Biztosítani kell a csapdázás és a szelektív gyérítési eljárások jogi és gazdasági feltételeit.

Nagy jelentőségő, hatékony. Felelős szervezet: FM Erdészeti és vadgazdálkodási Főosztály

\section{Tanácsadás, oktatás}

C3.1. Minden lehetséges módon (különösen a hivatásos vadász továbbképzéseken) meg kell ismertetni a gazdálkodókkal a dolmányos varjú (általában a dúvad fajok) tényleges vadgazdálkodási jelentőségét, predációs súlyát, szabályozásának jogi lehetőséget, technikai eszköztárát és a jó gyakorlatot.

Nagy fontosságú, nagy hatékonyságú. Felelős: OMVV, OMVK országos és megyei területi szervezetei, NyME-EMK Vadgazdálkodási és Gerinces Állattani Intézet.

\section{Kutatás és monitoring}

A kutatás során az alábbi prioritásokat kell szem előtt tartani:

C.4.1. Populáció diszperziója, szaporodási viszonyai

C.4.2 Táplálkozása megváltozott körülmények között

C.4.3. Élőhely-monitoring (fészkelőhely, táplálkozóhely)

C.4.4. A vadászati nyomás vizsgálata

C.4.5. Csapdázási eredményesség elemzése

Nagy fontosságú, közepes hatékonyságú. Felelös: Földmüvelésügyi Minisztérium, megyei vadászati hatóságok, NymE-EMK Vadgazdálkodási és Gerinces Állattani Intézet, SZIE Vadvilág Megőrzési Intézet

\section{Kommunikáció és nyilvánosság}

C.5.1. A dúvadgazdálkodás hatékonysága és elfogadtatása érdekében a vadgazdálkodásnak jó kapcsolatokat kell kialakítani valamennyi hatósággal.

Nagy jelentőségü, nagy hatékonyságú. Felelös: FM, Kormányhivatalok

C.5.2. Kellö rendszerességgel tájékoztatni kell a nagyközönséget a dúvadgazdálkodás fontosságáról, helyzetéröl.

Nagy fontosságú, közepes hatékonyságú. Felelős: megyei vadászati hatóságok, OMVV, OMVK, NymE-EMK Vadgazdálkodási és Gerinces Állattani Intézet, SZIE Vadvilág Megörzési Intézet

\section{IRODALOMJEGYZÉK}

BANKovics A. \& VADÁsz Cs. (2009): Dolmányos varjú - Corvus cornix Linnaeus, 1758. - Kormos varjú - Corvus corone Linnaeus, 1758. In: CSÖRGÖ T., KARCZA Zs., HALMOS G., MAGYAR G. GYURÁCZ J., SZÉP T., BANKOVICS A., SCHMIDT A. \& SCHMIDT E. (szerk.): Magyar madárvonulási atlasz. Kossuth kiadó. pp. 580-581.

BIRDLIFE INTERNATIONAL/EUROPEAN BIRD CENSUS COUNCIL (2000): European bird population: estimates and trends. Cambridge, UK: BirdLife International, BirdLife Conservation Series 10. $160 \mathrm{p}$.

BirdLiFE INTERNATIONAL (2004): Birds in Europe. Population estimates, trends and conservation status. Cambridge, UK: BirdLife International (BirdLife Conservation Series No. 12.). 374 p.

BuB, H. (1995). Bird Trapping \& Bird Banding: A handbook for trapping methods all over the world. Ithaca, New York: Cornell University Press. 
CsABA, J. (1963): Das Vorkommen der Rabenkrähe (Corvus corone L.) und ihrer Bastarde in WestUngarn. Savaria 1: 39-48.

CSÁNYI S. (szerk.) (1999): Vadgazdálkodási Adattár, 1994-1998. Gödöllő, Országos Vadgazdálkodási Adattár.

CSÁNYI S. (szerk.) (2001): Vadgazdálkodási Adattár - 2000/2001. vadászati év. Országos Vadgazdálkodási Adattár, Gödöllő.

CSÁNYI S. (szerk.) (2005): Vadgazdálkodási Adattár - 2004/2005. vadászati év. Országos Vadgazdálkodási Adattár, Gödöllő.

CSÁNYI S. (2015) (szerk.): A 2014/2015. vadászati év vadgazdálkodási eredményei valamint a 2015. tavaszi vadállomány-becslési adatok és vadgazdálkodási tervek. Országos Vadgazdálkodási Adattár, Gödöllő. 152 p.

CsÁNyi S., LeHOCZKy R. \& Sonkoly K. (szerk.) (2005): Vadgazdálkodási Adattár - 2005/2006. vadászati év. Országos Vadgazdálkodási Adattár, Gödöllő. 64 p.

CSÁNYI S., LEHOCZKY R. \& SONKOlY K. (szerk.) (2008): Vadgazdálkodási Adattár - 2007/2008. vadászati év. Országos Vadgazdálkodási Adattár, Gödöllő. 64 p.

CSÁNYI S., LEHOCZKY R. \& SONKOLY K. (szerk.) (2010): Vadgazdálkodási Adattár - 2009/2010. vadászati év. Országos Vadgazdálkodási Adattár, Gödöllő. 56 p.

CSÁNYI S., LEHOCZKY R. \& SONKOLY K. (szerk.) (2012a): Vadgazdálkodási Adattár - 2010/2011. vadászati év. Országos Vadgazdálkodási Adattár, Gödöllő. 52 p.

CSÁNYI S., LEHOCZKY R. \& SONKOLY K. (szerk.) (2012b): Vadgazdálkodási Adattár - 2011/2012. vadászati év. Országos Vadgazdálkodási Adattár, Gödöllő. 52 p.

CsÁNyi S., Tóth K. \& SChally G. (szerk.) (2012c): Vadgazdálkodási Adattár - 2012/2013. vadászati év. Országos Vadgazdálkodási Adattár, Gödöllő. 52 p.

CSÁNyi S., TÓTH K., KovÁcs I. \& Schally G. (szerk.) (2014): Vadgazdálkodási Adattár 2013/2014. vadászati év. Országos Vadgazdálkodási Adattár, Gödöllö. 48 p.

CSIKI E. (1914): Biztos adatok madaraink táplálkozásáról - Kilencedik közlemény. 58. Corvus cornix L. Aquila 21: 210-221.

DeCKERT, G. (1980): Siedlungsdichte und Nahrungssuche bei Elster, Pica p. pica (L.) und Nebelkrähe, Corvus corone cornix. Beiträge zur Vogelkunde 26 (6): 305-334.

FARAGÓ S. (1991): Vizsgálatok a szárnyasvad állati eredetű táplálékbázisáról mezőgazdasági környezetben Magyarországon. I. A szárnyasvad tápláléka, a táplálékbázis-vizsgálatok anyaga és módszere. EFE Tudományos Közleményei 1989(2): 153-192.

FARAGÓ S. (2001a): Adatok a magyarországi mezei szárnyasvad fajok fészekalj nagyságaihoz és tojásméreteihez. Magyar Apróvad Közlemények 6: 113-132.

FARAGÓ S. (2001b): Mezei szárnyasvad fajok vonulása Magyarországon, jelölt madarak megkerülése alapján. Magyar Apróvad Közlemények 6: 133-161.

FARAGÓ S. (2006): Varjúfélék vadászata. In: FARAGÓ S. (szerk.): Magyar Vadász Enciklopédia. Totem Kiadó, Budapest. pp. 519-520.

FARAGÓ S. (2015): Vadászati állattan. Negyedik, átdolgozott kiadás. Mezőgazda Kiadó Budapest.

FARAGÓ S., JÁNOSKA F., DITTRICH G. \& GICZI F. (2012): Varjúfélék (Corvidae) állomány- és teríték monitoringja a LAJTA Projectben. In: FARAGÓ S. (szerk.): A LAJTA Project. Egy tartamos mezei vad és ökoszisztéma vizsgálat 20 éve. Nyugat-magyarországi Egyetem Kiadó, Sopron. pp. 353-363.

FARAGÓ S. \& NÁHLIK A. (1997): A vadállomány szabályozása. A fenntartható vadgazdálkodás populációökológiai alapjai. Mezőgazda Kiadó, Budapest. 315 p.

FERIANC, O. (1979): Vtáky Slovenska 2. Vyd. Slov. Akad. Vied, Bratislava.

GlutZ VON BlOtZHeIM, U.N. \& BAUER, K.M. (1993): Handbuch der Vögel Mitteleuropas. Band 13/III. Passeriformes (4. Teil Corvidae - Sturnidae). Aula Verlag, Wiesbaden.

HAJAS P.P. (2007): Csapdázással a Fogoly Repatriációs Program sikeréért. Nimród Vadászújság 95 (11): 21.

HAJAS P.P. (2009). Az élvefogó csapdák alkalmazásának tapasztalatai a szőrmés és szárnyas kártevők korlátozásában. In: NAGY, E. (szerk.): Vadgazdálkodásunk fejlesztésének lehetöségei. A vadgazdálkodás idöszerü kérdései 9. pp. 59-64.

HAJAS P.P. (2011): Oldalajtós Larsen-csapda. Magyar Vadászlap 20 (4): 267. 
HAJAS P.P. (2012): A Larsen-csapda északi változata: Trolle-Ljungby L84. Magyar Vadászlap 21(5): 316.

HARRISON, C. (1975): Jungvögel, Eier und Nester aller Vögel Europas, Nordafrikas und des Mittleren Ostens. Verlag Paul Parey, Hamburg und Berlin.

Houston, D. (1997): Carrion Crow. In: HAGEMEIJER, W.J.M. \& Blair, M.J. (szerk.) (1997): The EBCC Atlas of European Breeding Birds: Their distribution and abundance. T and D Poyser, London

HudEC, K. (szerk.) (1983): Ptáci - Aves III/2. Fauna Cssr. Academia, Praha.

Jonsson, L. (1993): Birds of Europe with North-Africa and Middle East. C. Helm Publisher Ltd/A. \& C. Black Publisher Ltd. London.

KALOTÁs Zs. (1988): Adatok a dolmányos varjú (Corvus corone cornix L.) és a szarka (Pica pica) magyarországi állományviszonyaihoz. Aquila 95: 162-170.

KALOTÁS, Zs. \& NiKODÉMUSZ, E. (1982): Controlling magpies (Pica pica) and hooded crow (Corvus cornix) with 3-chloro-4-methylaniline-HCl using egg-baits. Zeitschrift für Angewandte Zoologie 69 (3): 275-281.

KARLSSON, B. (2009). Fångst av kråkfåglar. Svenska jägareförbundets Förlag, Stockholm

KeVE A. (1960): Magyarország madarainak névjegyzéke. Nomenclator avium

KeVE, A. (1972): Systematische Studien über die Corviden des Karpatenbeckens, nebst einer Revision ihrer Rassenkreise. IV. Corvus cornix L. Vertebrata Hungarica 13: 105-162.

KeVE A. (1984): Magyarország madarainak névjegyzéke. Nomenclator avium Hungariae. Akadémiai Kiadó, Budapest. 100 p.

KOSARAS Z. (1986): A dolmányos varjú (Corvus cornix) és a szarka (Pica pica) gazdasági jelentösége és állományapasztásának lehetőségei. Diplomamunka, Erdészeti és Faipari Egyetem, Vadgazdálkodási Tanszék, Sopron. 51 p.

MAdGe, S. (2016a): Carrion crow (Corvus corone). In: Del Hoyo, J., ElliotT, A., SARGatal, J., Christie, D. A. \& DE JUANA, E. (szerk.): Handbook of of the Birds of the World Alive. Lynx Edicions, Barcelona. (retrieved from http://www.hbw.com/node/60794 on 22 June 2016)

MadGe, S. (2016b): Hooded crow (Corvus cornix). In: DEl Hoyo, J., ElliotT, A., SARGatal, J., Christie, D. A. \& DE JUANA, E. (szerk.): Handbook of of the Birds of the World Alive. Lynx Edicions, Barcelona. (retrieved from http://www.hbw.com/node/60795 on 22 June 2016)

MAGYAR G., HADARICS T., WALICZKY Z., SCHMIDT A. \& BANKOVICS A. (1998): Nomenclator Avium Hungariae. Magyarország madarainak névjegyzéke. Madártani Intézet - MME - Winter Fair, Budapest-Szeged. 202 p.

MAKATSCH, W. (1976): Die Eier der Vögel Europas. Band 2. Neumann Verlag, Lepzig-Radebeul.

MELDE, M. (1984): Raben- und Nebelkrähe Corvus corone. Neue Brehm Bücherei. A. Ziemsen Verlag, Wittenberg Lutherstadt. 2. Auflage

MME NOMENCLATOR BIZOTTSÁG (2008): Magyarország madarainak névjegyzéke. Nomenclator avium Hungariae. An annotated list of the birds of Hungary. Magyar Madártani és Természetvédelmi Egyesület, Budapest. 278 p.

PotTs, G.R. (1986): The Partridge. Pesticides, Predation and Conservation. Collins, London. 274 p.

SAULNIER, J.C. (2008). L'incontournable du piégeur. Le Mesnil le Roi: Editions Chasse-Sports.

STERBETZ, I. (1968): A magyarországi szürkevarjak táplálkozásának újabb értékelése. Aquila 75: 151157.

TAPPeR, S., Swan, M. \& Reynolds, J. (1991): Larsen Traps: A survey of members' results. The Game Conservancy Review of 1990, Vol. 22., pp. 82-86.

TUCKER, G.M. \& HEATH, M.F. (1994): Birds in Europe: their conservation status. Cambridge, U.K. BirdLife Conservation Series 3.

Westerkamp, A. (2006). Fangjagd. Franckh-Kosmos Verlags GmbH \& Co. KG. Czech Republic. 